\title{
Fusarium Toxins in Chinese Wheat since the 1980s
}

\author{
Jianbo Qiu ${ }^{1}$, Jianhong $X u^{1,2, *}$ and Jianrong Shi ${ }^{1,2, *}$ \\ 1 Key Laboratory for Control Technology and Standard for Agro-product Safety and Quality, Ministry of \\ Agriculture and Rural Affairs/Jiangsu Key Laboratory for Food Quality and Safety-State Key Laboratory \\ Cultivation Base, Ministry of Science and Technology/Collaborative Innovation Center for Modern Grain \\ Circulation and Safety/Institute of Food Safety and Nutrition, Jiangsu Academy of Agricultural Sciences, \\ Nanjing 210014, China; qiujianbo19850901@126.com \\ 2 School of Food and Biological Engineering, Jiangsu University, Zhenjiang 212013, China \\ * $\quad$ Correspondence: xjh@jaas.ac.cn (J.X.); shiji@jaas.ac.cn (J.S.)
}

Received: 4 April 2019; Accepted: 27 April 2019; Published: 30 April 2019

\begin{abstract}
Wheat Fusarium head blight (FHB), caused by Fusarium species, is a widespread and destructive fungal disease. In addition to the substantial yield and revenue losses, diseased grains are often contaminated with Fusarium mycotoxins, making them unsuitable for human consumption or use as animal feed. As a vital food and feed ingredient in China, the quality and safety of wheat and its products have gained growing attention from consumers, producers, scientists, and policymakers. This review supplies detailed data about the occurrence of Fusarium toxins and related intoxications from the 1980s to the present. Despite the serious situation of toxin contamination in wheat, the concentration of toxins in flour is usually lower than that in raw materials, and food-poisoning incidents have been considerably reduced. Much work has been conducted on every phase of toxin production and wheat circulation by scientific researchers. Regulations for maximum contamination limits have been established in recent years and play a substantial role in ensuring the stability of the national economy and people's livelihoods.
\end{abstract}

Keywords: China; wheat; Fusarium species; mycotoxicoses; Fusarium toxins; toxin management

Key Contribution: This review gives an overview of scientific data about wheat contamination with main Fusarium mycotoxins and Fusarium species in the past 40 years. Furthermore; the efforts for toxin management by the government and scientists are described.

\section{Introduction}

Wheat (Triticum aestivum L.), which belongs to the grass family, is widely distributed throughout the world and has a large planting area and total yield. Wheat is not only a vital nutrient-rich food source but also an important industrial raw material and animal feed component, and its distribution and use in China is similar to its global characteristics. With the adjustment of the agricultural structure, wheat has been the third largest food crop after maize and rice. According to the relevant data from the 2018 China Statistical Yearbook, wheat acreage has stabilized at $245,080 \mathrm{~km}^{2}$ over the past ten years, accounting for $14.73 \%$ of cereal production in 2017. China's total production of wheat has reached 134 million tons and has increased 22\% from 2007. However, despite the increase, the deficit in the trade balance increased to a billion dollars, which means that China needs to import approximately 4.4 million tons of wheat every year; this importation makes it imperative to breed wheat for increased yield. China is the largest wheat producer, supplying $17 \%$ of the total yield globally. More importantly, China is also the largest wheat consumer and accounts for $16 \%$ of the total consumption of wheat every year [1]. Wheat flour-based products, such as steamed buns and noodles, are staple foods for more than 
half of China's population and can be traced back thousands of years. Thus, assuring the quality and safety of wheat and its products is vitally significant to the national economy and people's livelihoods.

Like other crops, due to the influence of agricultural environments and inputs, there are various safety issues, such as heavy metals and pesticide residues, in wheat-derived products, [2,3]. According to previous studies, mycotoxins are an even greater challenge for wheat quality [4-6]. Fusarium head blight (FHB), or scab, mainly caused by members of the Fusarium graminearum species complex (FGSC), is a destructive fungal disease in most of the world's major wheat-growing areas [7]. From an economic perspective, FHB seriously affects wheat yield, resulting in income reductions for farmers and a substantial financial loss to society. Recently, the impact of FHB on food safety and human health has aroused considerable public concern because the diseased grains are frequently contaminated with toxic secondary metabolites. Among these, type B trichothecenes and zearalenone (ZEN) are the most serious and prevalent toxins in China. Trichothecenes, mainly deoxynivalenol (DON), 3-acetyl-deoxynivalenol (3ADON), 15-acetyl-deoxynivalenol (15ADON), and nivalenol (NIV), can cause acute poisoning symptoms, such as vomiting and dizziness in humans and weight loss and anorexia in animals. The mechanism of action of trichothecenes is based on the inhibition of protein synthesis [8]. Additionally, DON presents immunotoxicity, cytotoxicity, teratogenicity, and carcinogenicity [9-12]. ZEN and its metabolites have strong estrogenic activities and can cause reproductive alterations [13]. ZEN is also reported to be hepatotoxic, hematotoxic, immunotoxic and genotoxic [14]. Therefore, even low levels of these toxins in raw grains can make them hazardous to human or animal health.

Concerning the possible substantial effect of toxins on the country's economy and society, the Chinese government has made many efforts aimed at ensuring cereal safety, such as setting strict limit and rigorous analytical method standards, revising agricultural product quality security laws, and establishing national special projects for agro-product safety risk evaluations. Fusarium toxins are produced by Fusarium species in suitable environmental conditions, and once they were present, there is no effective way to completely eliminate them from food. Even so, agricultural scientists have developed physical, chemical and biological methods to interfere with Fusarium species infection and toxin accumulation in all phases of wheat production. The present review aims to systematically analyze the occurrence characteristics of the main Fusarium toxins in wheat, the varying trend in human poisoning incidents, and the utility of toxin management measures in the past 40 years to provide a reference for scientific monitoring and effective prevention and control of mycotoxin contamination in China.

\section{Human Mycotoxicoses Caused by Fusarium Toxins}

Wheat flour and its products have always accounted for a large proportion of the traditional Chinese diet and have a long history, especially in the north of the country. Due to the widespread occurrence and the complicated toxic effects of poisonous FHB metabolites, their presence in food should be regarded as a potential food safety hazard. Mycotoxicosis outbreaks in humans have been associated with the intake of food contaminated with these toxins and are thus a matter of great concern to consumers.

Historically, there were several reports about mycotoxicoses in humans after the consumption of scabby wheat grains, particularly in the 1980s. A total of 21 outbreaks of human intoxication occurred successively from 1984 to 1991 in the main wheat-growing provinces [15]. Some cases of scabby wheat-related food poisoning published in professional journals are listed in Table 1 . The typical clinical symptoms are gastrointestinal disorders, including abdominal pain and fullness, nausea, diarrhea, vomiting, fatigue, and fever. 
Table 1. Outbreaks of moldy wheat-related food-poisoning incidents in humans since the 1980s.

\begin{tabular}{ccccc}
\hline Year & Region & Consumer & Victim & Reference \\
\hline 1985 & Lingtao, Gansu & 1549 & 1351 & {$[16]$} \\
1985 & Puyang, Henan & 217 & 101 & {$[17]$} \\
1988 & Yulin, Guangxi & 160 & 40 & {$[18,19]$} \\
1988 & Tongshan, Jiangsu & 9 & 9 & {$[20]$} \\
1989 & Zigong, Sichuan & 7 & 7 & {$[21]$} \\
1989 & Baihe, Shannxi & 5016 & 701 & {$[21]$} \\
1991 & Xincai, Henan & 840 & 479 & {$[22]$} \\
1991 & Linquan, Anhui & 93 & 67 & {$[23]$} \\
1991 & Fuyang, Anhui & 354 & 263 & {$[24]$} \\
1991 & Xuyi, Jiangsu & 141 & 117 & {$[24]$} \\
1996 & Putian, Fujian & 3 & 2 & {$[25]$} \\
2000 & Kedong, Helongjiang & 6 & 6 & {$[26]$} \\
2003 & Dongming, Shandong & 4 & 4 & {$[27]$} \\
2003 & Baihe, Shannxi & 5043 & 701 & {$[28]$} \\
\hline
\end{tabular}

In 1985, a severe FHB epidemic occurred in wheat in a suburb of Puyang County, Henan Province. A large proportion of local inhabitants showed typical symptoms including gastrointestinal disorders and nervous system disturbances after eating scabby wheat grains, and the incidence of related diseases was $45 \%$ [17]. Most of the patients returned to health after two hours of symptoms. After this incident, DON was considered the most important causative toxicant responsible for human intoxications.

After a large flood in 1991, extensive outbreaks of human toxicoses affecting a large number of people who consumed moldy wheat grains occurred in parts of Henan, Anhui, and Jiangsu provinces, as appropriate conditions, such as heavy rainfall and low temperature, for an FHB epidemic and mycotoxin production occurred after the flood [22-24]. High amounts of DON were found in food that was linked to an episode of 'red-mold intoxication' involving 130,000 people with acute gastrointestinal disorders in Anhui Province in 1991 [29].

In the 21st century, human poisoning caused by Fusarium toxins decreased and moved from group outbreaks to individual incidents. For example, in 2000, a whole family in Northeast China developed acute poisoning symptoms twice after eating products derived from flour from home-grown wheat [27]. The latest large-scale food safety incident reported in Northwest China was demonstrated to be associated with the consumption of flour products processed from diseased wheat grains. In 2003, of 5043 people in 10 villages who consumed contaminated foods, 701 (13.9\%, no lethal cases) presented intoxication. The most common symptoms of the victims were nausea, numbness of the throat, and a burning sensation of the esophagus; symptoms disappeared within approximately 3 hours without medical attention. This human food toxicity incident happened in June and July, when large quantities of wheat grains became moldy but were still harvested despite inferior quality resulting from long-term precipitation. Other reasons for this large-scale incident were a lack of health awareness and poor traditional eating habits of the local residents [28].

In addition to acute toxicity, Fusarium toxins are associated with some human chronic diseases (Table 2). Kashin-Beck disease (KBD) is a chronic, endemic osteochondropathy that occurs mainly in the distant provinces of northeastern and northwestern China [30]. In KBD-endemic areas, wheat has been frequently infected with Fusarium species, and the disease has been suspected to be associated with the consumption of Fusarium-contaminated grains. Earlier findings by Luo et al. [31] on the level of Fusarium toxins in wheat from Shanxi and Inner Mongolia found that the prevalence rate and content of DON 3ADON, NIV, and ZEN were significantly higher in the high-risk area of KBD than in the low-risk area. It seemed that there was a dose-effect relationship between toxins contamination level and degree of KBD occurrence. In Qinghai Province, the DON content in the wheat flour samples from the KBD area was significantly higher than that of the non-KBD area, and the authors indicated that the characteristic distribution of DON contamination in wheat flour was consistent with the KBD prevalence [32]. Similar results regarding DON contamination were reported in wheat flour from Shandong and Gansu provinces [33]. However, the precise etiology of KBD was still not clearly defined, and T-2 toxin and selenium levels were implicated as important causes. Fortunately, a recent epidemiological investigation reported that the KBD prevalence decreased from 1990 to 2007 [34]. 
Table 2. Occurrence of Fusarium toxins in high KBD or cancer incidence regions.

\begin{tabular}{|c|c|c|c|c|c|c|c|}
\hline Year & Regions & Sample Size & Toxin & Incidence (\%) & $\begin{array}{c}\text { Average Content } \\
(\mu \mathrm{g} / \mathrm{kg})\end{array}$ & Content $(\mu \mathrm{g} / \mathrm{kg})$ & Reference \\
\hline \multirow{16}{*}{1989} & \multirow{4}{*}{$\begin{array}{c}\text { Shannxi } \\
\text { (KBD high incidence) }\end{array}$} & \multirow{4}{*}{5} & DON & 100.0 & 514.0 & $343.0-1051.0$ & \multirow{16}{*}{ [31] } \\
\hline & & & $3 \mathrm{ADON}$ & 100.0 & 363.0 & 15.0-731.0 & \\
\hline & & & NIV & 100.0 & 183.0 & $17.0-373.0$ & \\
\hline & & & ZEN & 40.0 & 15.0 & $5.0-25.0$ & \\
\hline & & & DON & 100.0 & 184.0 & $73.0-410.0$ & \\
\hline & Shannxi & 5 & $3 \mathrm{ADON}$ & 0 & 0 & 0 & \\
\hline & (KBD low incidence) & 5 & NIV & 60.0 & 10.0 & $8.0-13.0$ & \\
\hline & & & ZEN & 0 & 0 & 0 & \\
\hline & \multirow{4}{*}{$\begin{array}{c}\text { Inner Mongolia } \\
\text { (KBD high incidence) }\end{array}$} & \multirow{4}{*}{6} & DON & 100.0 & 101.0 & & \\
\hline & & & $3 \mathrm{ADON}$ & 50.0 & 24.0 & & \\
\hline & & & NIV & 33.3 & 9.0 & & \\
\hline & & & ZEN & 0 & 0 & 0 & \\
\hline & \multirow{4}{*}{$\begin{array}{l}\text { Inner Mongolia } \\
\text { (KBD low incidence) }\end{array}$} & \multirow{4}{*}{7} & DON & 100.0 & 75.0 & & \\
\hline & & & 3ADON & 28.6 & 57.0 & & \\
\hline & & & NIV & 0 & 0 & 0 & \\
\hline & & & ZEN & 0 & 0 & 0 & \\
\hline \multirow{2}{*}{2010} & $\begin{array}{c}\text { Qinghai } \\
\text { (KBD high incidence) }\end{array}$ & 23 & DON & 87.0 & 302.0 & & \multirow[t]{2}{*}{ [32] } \\
\hline & $\begin{array}{l}\text { Qinghai } \\
\text { (non-KBD) }\end{array}$ & 27 & DON & 29.6 & 199.0 & & \\
\hline \multirow{5}{*}{2010} & \multirow{3}{*}{$\begin{array}{c}\text { Gansu } \\
\text { (KBD high incidence) }\end{array}$} & 20 & DON & 75.0 & 142.8 & $12.8-205.3$ & \multirow{5}{*}{ [33] } \\
\hline & & 20 & DON & 80.0 & 137.4 & $28.5-180.7$ & \\
\hline & & 20 & DON & 75.0 & 127.3 & $20.6-176.1$ & \\
\hline & Shandong & 20 & $\mathrm{DON}$ & 10.0 & 12.9 & $10.2-15.6$ & \\
\hline & (KBD low incidence) & 20 & DON & 20.0 & 18.1 & $8.9-27.3$ & \\
\hline \multirow{4}{*}{1989} & \multirow{2}{*}{$\begin{array}{c}\text { Henan Linxian } \\
\text { (esophageal cancer high risk) }\end{array}$} & 15 & DON & 46.7 & 59.0 & $7.0-309.0$ & \multirow{4}{*}{ [35] } \\
\hline & & 15 & NIV & 0 & 0 & 0 & \\
\hline & Henan Shangqiu & 15 & DON & 46.7 & 18.0 & $7.0-36.0$ & \\
\hline & (esophageal cancer low risk) & 15 & NIV & 46.7 & 15.0 & $13.0-21.0$ & \\
\hline
\end{tabular}


Table 2. Cont

\begin{tabular}{|c|c|c|c|c|c|c|c|}
\hline Year & Regions & Sample Size & Toxin & Incidence (\%) & $\begin{array}{l}\text { Average Content } \\
(\mu \mathrm{g} / \mathrm{kg})\end{array}$ & Content $(\mu \mathrm{g} / \mathrm{kg})$ & Reference \\
\hline \multirow{6}{*}{1995} & \multirow{3}{*}{$\begin{array}{c}\text { Linxian, Henan } \\
\text { (esophageal cancer high risk) }\end{array}$} & \multirow{3}{*}{25} & DON & \multirow{3}{*}{92.0} & 83.0 & $9.0-193.0$ & \multirow{12}{*}[36,37]{} \\
\hline & & & $15 \mathrm{ADON}$ & & 0 & 0 & \\
\hline & & & NIV & & 29.0 & $13.0-50.0$ & \\
\hline & \multirow{3}{*}{$\begin{array}{c}\text { Henan Shangqiu } \\
\text { (esophageal cancer low risk) }\end{array}$} & \multirow{3}{*}{15} & DON & & 40.0 & $15.0-125.0$ & \\
\hline & & & $15 \mathrm{ADON}$ & 60.0 & 0 & 0 & \\
\hline & & & NIV & & 12.0 & $4.0-22.0$ & \\
\hline \multirow{6}{*}{1997} & \multirow{3}{*}{$\begin{array}{c}\text { Linxian, Henan } \\
\text { (esophageal cancer high risk) }\end{array}$} & \multirow{3}{*}{15} & DON & \multirow{3}{*}{66.7} & 28.0 & $0-138.0$ & \\
\hline & & & $15 \mathrm{ADON}$ & & 0 & 0 & \\
\hline & & & NIV & & 95.0 & & \\
\hline & \multirow{3}{*}{$\begin{array}{c}\text { Henan Shangqiu } \\
\text { (esophageal cancer low risk) }\end{array}$} & \multirow{3}{*}{15} & DON & \multirow{3}{*}{0} & 0 & 0 & \\
\hline & & & $15 \mathrm{ADON}$ & & 0 & 0 & \\
\hline & & & NIV & & 0 & 0 & \\
\hline \multirow{4}{*}{2000} & Linxian, Henan & 9 & DON & 77.8 & 732.0 & $0-1614.0$ & \multirow{4}{*}[38]{} \\
\hline & (esophageal cancer high risk) & 11 & NIV & 100.0 & 666.0 & 190.0-1476.0 & \\
\hline & Cixian, Hebei & 18 & DON & 100.0 & 1031.0 & $176.0-4280.0$ & \\
\hline & (esophageal cancer low risk) & 18 & NIV & 100.0 & 731.0 & 102.0-2105.0 & \\
\hline \multirow{4}{*}{2010} & Shandong & 20 & \multirow{4}{*}{ DON } & 100.0 & 195.2 & $70.1-302.8$ & \multirow{4}{*}{ [39] } \\
\hline & (esophageal cancer high risk) & 20 & & 100.0 & 184.3 & $85.4-287.5$ & \\
\hline & Shandong & 20 & & 10.0 & 12.9 & $10.2-15.6$ & \\
\hline & (esophageal cancer low risk) & 20 & & 20.0 & 18.1 & $18.9-27.3$ & \\
\hline
\end{tabular}


During the process of researching the etiology of esophageal cancer, DON was found to be one of the predominating contaminating mycotoxins in the grains and foodstuffs in the high-incidence area in China [39]. Co-contamination of DON, 15ADON, and NIV in wheat samples from Henan Province, where cancer is highly prevalent, was studied in 1989, 1995 and 1997 [36,37]. Linxian samples showed higher levels of DON than those from Shangqiu, which has a low esophageal cancer incidence. These studies suggested that fungal contamination of foods and residents' exposure to mycotoxins could be considered possible factors involved in the development of cancer. In a survey of Shandong samples harvested in 2010, significantly higher levels of DON were identified in all wheat samples from high-risk areas than in wheat samples from low-risk areas [38]. Hsia et al. [39] reported that NIV naturally existed at high levels in dietary food in high-risk cancer areas and suggested that people who consumed a diet with high levels of NIV had a significantly greater risk of developing esophageal cancer than those who consumed a diet with low levels of NIV. The occurrence of esophageal cancer is a result of multiple factors, including the poor eating habits (tobacco smoking and alcohol drinking), the lack of nutrients and trace elements, genetic determinants, and the intake of food containing high concentration of nitrite compounds and mycotoxins. It is speculated that the chronic consumption of cereals contaminated with mycotoxigenic Fusarium species can increase the odds of the disease, although no correlation between Fusarium toxins and esophageal cancer has been published [40]. Nonetheless, as the most important natural poisons, the threat should not be taken lightly. In general, most outbreaks of human mycotoxicoses from Fusarium toxins followed the occurrence of severe FHB. In the last few years, the damage caused by FHB has become increasingly serious; however, the incidence and the number of victims of human mycotoxicoses have followed the opposite trend. Along with the improvement in living standards, moldy grains are no longer used for food, but they can still serve as major feed components for poultry and livestock. This harm to the development of the animal husbandry industry is not mentioned here, yet it needs to be solved urgently. There are three main causes for this phenomenon. The first is the development and popularization of science and technology. Consumers have a remarkable increase in the understanding and knowledge of scabby wheat and Fusarium toxins, thus contributing to the development of good eating habits. Another reason is the improvement of Chinese living standards. People have more dietary choices and can discard diseased or low-quality cereals. The regulatory authorities for all levels of agricultural product quality and safety also play a crucial role. Moldy wheat grains have been eliminated from the market, and the quality of wheat products is under strict surveillance; thus, safe and superior quality foods are provided to consumers. All these factors reduce the risk of the occurrence of food safety incidents.

\section{Toxin-Producing Fusarium Strains}

The first FHB outbreak in China can be traced back to 1936; scientists began to research the pathogen of this disease approximately 20 years later [41] and found that most strains from China can produce large amounts of DON and ZEN $[42,43]$. Based on relevant research in recent years, F. graminearum was identified as the main pathogen of FHB in China, despite the presence of a large variety of Fusarium species isolated from diseased wheat grains. As early as the 1980s, research on FHB pathogens in 21 provincial regions in China identified 18 Fusarium species, among which $F$. graminearum dominated and accounted for $94.5 \%$ of the total [44]. Subsequently, similar results were obtained from studies in Henan, Fujian, Hunan, Ningxia and Qinghai provinces [45-48]. 
In recent years, genetic and molecular approaches have led to a new understanding that narrowly defines F. graminearum sensu stricto (s. str.) as a species complex with significant genetic diversity, clear divergence of biological species, and an obvious geographical distribution. Currently, FGSC consists of at least 16 phylogenetically distinct species [49]. F. graminearum s. str. is the most widely distributed species and occurs in most FHB areas around the world [50], while F. asiaticum is the main FHB pathogen present in Asia [51,52].

FGSC species can produce several mycotoxins; type B trichothecenes are the most common toxic metabolites found in infected cereals [53]. FGSC strains usually present one of three trichothecene profiles: (i) deoxynivalenol and 3-acetyldeoxynivalenol (3ADON chemotype); (ii) deoxynivalenol and 15-acetyldeoxynivalenol (15ADON chemotype); or (iii) nivalenol and its acetylated derivatives (NIV chemotype) [54]. The chemotype composition appears to be species dependent [55]. In China, most of the $F$. graminearum s. str. isolates are $15 \mathrm{ADON}$ producers, while F. asiaticum isolates contain 3ADON and NIV chemotypes. Table 3 presents the trichothecene type compositions of F. graminearum s. str. and F. asiaticum in wheat.

In terms of geographic distribution, the vast majority of F. asiaticum isolates have been collected from warm southern areas $[56,57]$, and F. graminearum s. str. is mainly distributed in cool northern regions $[58,59]$. The composition of the populations has been stable over time. The population structure and genetic variation in FHB pathogens have been studied in detail in Jiangsu Province, which has a long history of rice growing and a large rice-growing area that covers 30 million acres. The F. asiaticum strain that produced $3 \mathrm{ADON}$ has always dominated [60,61], and no similar evidence of temporal trends in the North American wheat population or Chinese barley population has been found [62-66]. Extensive wheat-rice rotation is critical for F. asiaticum overwintering, and perithecium production typically favors rice straw under warmer conditions. The better fitness of F. asiaticum on rice and DON producers on wheat has led to the prevalence of $3 \mathrm{ADON}$-producing F. asiaticum in most wheat-rice rotation areas in Southern China. As a result, a 3ADON-producing F. asiaticum population may have been present in this region for a long time, and we suggest that this might have been the main factor underlying the absence of variation in trichothecene genotype frequencies from 1976 to 2014. Recently, based on available data from the literature, we concluded that a cropping system with wheat/maize rotation selects for F. graminearum, while a wheat/rice rotation selects for F. asiaticum [67].

Due to the promotion and application of straw-returning methods, more perithecia form and more ascospores are released in the subsequent year. Crop debris in the field feeds and increases the amount of primary FHB inoculum. Climatic or agricultural conditions favor wheat infection by Fusarium, which eventually leads to higher levels of toxins in wheat. A dominant FHB population means that the main toxins have been substantially retained over a long period of time, and the quantity of FHB pathogens is likely to continually increase. Based on this phenomenon, it can be assumed that the epidemic risk of FHB and harmful levels of Fusarium toxins could continue to increase for a long time in the future. 
Table 3. The ratio of F. graminearum and F. asiaticum strains with varied chemotypes in partial studies in China.

\begin{tabular}{|c|c|c|c|c|c|c|c|c|c|}
\hline Year & Region & Sample Sizes & Fg15ADON & Fg3ADON & FgNIV & Fa3ADON & FaNIV & Fa15ADON & Reference \\
\hline 1975-1980 & China & 2450 & \multicolumn{6}{|c|}{$94.5 \%$} & [44] \\
\hline 1975-1981 & Hunan & 185 & \multicolumn{6}{|c|}{$97.2 \%$} & [45] \\
\hline 1978-1981 & Fujian & 1081 & \multicolumn{6}{|c|}{$99.1 \%$} & [46] \\
\hline 1985 & Henan & 241 & \multicolumn{6}{|c|}{$98.0 \%$} & [47] \\
\hline 1985-1987 & Ningxia & 350 & \multicolumn{6}{|c|}{$63.8 \%$} & [48] \\
\hline 1991-1992 & Qinghai & 27 & \multicolumn{6}{|c|}{$56.5 \%$} & [68] \\
\hline 1993-1995 & Qinghai & 1005 & \multicolumn{6}{|c|}{$54.3 \%$} & [69] \\
\hline 1999 & China & 299 & \multicolumn{2}{|l|}{$22.7 \%$} & \multicolumn{2}{|r|}{$51.8 \%$} & $17.7 \%$ & $7.7 \%$ & [55] \\
\hline 2000 & Zhejiang & 208 & & & \multicolumn{2}{|r|}{$42.3 \%$} & $57.7 \%$ & & [56] \\
\hline 2007-2014 & Henan & 327 & \multicolumn{2}{|l|}{$89.0 \%$} & & $6.7 \%$ & $0.9 \%$ & $0.3 \%$ & [70] \\
\hline 2008 & China & 444 & \multicolumn{2}{|l|}{$38.1 \%$} & & $38.5 \%$ & $21.9 \%$ & $1.6 \%$ & [71] \\
\hline \multirow{6}{*}{2008} & Sichuan & 90 & $6.7 \%$ & $3.3 \%$ & $3.3 \%$ & $25.56 \%$ & $52.2 \%$ & & \multirow{6}{*}{ [72] } \\
\hline & Chongqing & 6 & $33.3 \%$ & & & & $66.7 \%$ & & \\
\hline & Hubei & 201 & $12.4 \%$ & $8.0 \%$ & $0.5 \%$ & $58.7 \%$ & $4.5 \%$ & $10.5 \%$ & \\
\hline & Henan & 25 & $100.0 \%$ & & & & & & \\
\hline & Anhui & 42 & $45.2 \%$ & $7.1 \%$ & $4.8 \%$ & $35.7 \%$ & $7.1 \%$ & & \\
\hline & Jiangsu & 69 & $15.9 \%$ & $10.1 \%$ & & $63.8 \%$ & $10.1 \%$ & & \\
\hline \multirow{6}{*}{ 2008-2010 } & Jiangsu & 292 & $5.5 \%$ & & & $84.6 \%$ & $9.9 \%$ & & \multirow{6}{*}[73]{} \\
\hline & Anhui & 71 & $21.1 \%$ & & & $59.2 \%$ & $19.7 \%$ & & \\
\hline & Henan & 88 & $89.8 \%$ & & & $8.0 \%$ & $2.3 \%$ & & \\
\hline & Hebei & 23 & $100.0 \%$ & & & & & & \\
\hline & Shandong & 31 & $83.8 \%$ & & & $12.9 \%$ & $3.2 \%$ & & \\
\hline & Hubei & 25 & $92.0 \%$ & & & & $8.0 \%$ & & \\
\hline
\end{tabular}


Table 3. Cont.

\begin{tabular}{|c|c|c|c|c|c|c|c|c|c|}
\hline Year & Region & Sample Sizes & Fg15ADON & Fg3ADON & FgNIV & Fa3ADON & FaNIV & Fa15ADON & Reference \\
\hline 2008 & \multirow{2}{*}{ Fujian } & 59 & & & & & $76.0 \%$ & $24.0 \%$ & \multirow{2}{*}{ [57] } \\
\hline 2009 & & 100 & & & & $4.0 \%$ & $81.0 \%$ & $15.0 \%$ & \\
\hline 2009 & Hubei & 168 & $9.5 \%$ & & & $69.6 \%$ & $6.6 \%$ & $7.7 \%$ & [74] \\
\hline 2011-2012 & Shandong & 95 & $94.7 \%$ & $4.4 \%$ & $1.1 \%$ & & & & {$[75]$} \\
\hline 2011 & Jiangsu/Anhui & 350 & $4.0 \%$ & $4.0 \%$ & & $82.9 \%$ & $4.3 \%$ & $4.9 \%$ & \multirow{2}{*}[60]{} \\
\hline 2012 & Jiangsu/Anhui & 541 & $8.7 \%$ & $1.5 \%$ & & $75.1 \%$ & $9.4 \%$ & $5.4 \%$ & \\
\hline 2013 & $\begin{array}{l}\text { Northeast } \\
\text { China }\end{array}$ & 118 & & $64.4 \%$ & & & & & [58] \\
\hline \multirow{5}{*}{2014} & Sichuan & 103 & $18.5 \%$ & & & $7.8 \%$ & $71.8 \%$ & $1.0 \%$ & \multirow{5}{*}{ [67] } \\
\hline & Hubei & 57 & & & & $87.7 \%$ & $7.0 \%$ & $5.3 \%$ & \\
\hline & Anhui & 93 & $1.1 \%$ & & & $87.1 \%$ & $10.8 \%$ & $1.1 \%$ & \\
\hline & Jiangsu & 67 & $3.0 \%$ & & & $89.6 \%$ & $7.5 \%$ & & \\
\hline & Fujian & 217 & $2.8 \%$ & & & $10.6 \%$ & $67.7 \%$ & $18.9 \%$ & \\
\hline 2014-2015 & Shandong & 120 & $84.2 \%$ & $4.2 \%$ & $1.7 \%$ & $10.0 \%$ & & & [76] \\
\hline 2016 & $\begin{array}{l}\text { Northeast } \\
\text { China }\end{array}$ & 84 & $44.1 \%$ & $3.6 \%$ & & $1.2 \%$ & $4.8 \%$ & $22.6 \%$ & [59] \\
\hline
\end{tabular}




\section{Natural Occurrence of Fusarium Toxins in Wheat}

China is a traditional agricultural country, and wheat is an important food ingredient. FHB severity has exhibited an increasing trend; therefore, the investigation of and surveillance for Fusarium toxins in wheat and its products are of great significance. Tables 4 and 5 show the main Fusarium toxins in wheat grains and wheat flour, respectively.

Fusarium toxin contamination shows various regional differences. The mean content and standard-exceeded rate of toxin was the highest in wheat and flour samples from Anhui and Jiangsu provinces, where FHB occurred severely and frequently. During the wheat heading and flowering period, a high temperature and humidity environment in the middle and lower reaches of the Yangtze River provided favorable conditions for the propagation of Fusarium, the occurrence of the disease and the accumulation of toxins. Although recent trends have indicated that FHB is spreading towards Northeast and Northwest China, the wheat quality in these regions is high. For example, a minimal incidence and concentration of DON and ZEN was detected in wheat from Heilongjiang [59]. A recent study reported the prevalence and concentration of DON in wheat harvested during 2013 from the northwest regions of China, suggesting varied and low levels of DON contamination in the region [77]. Especially in Xinjiang and Tibet, the safety quality of wheat and flour is in good condition [77-79]. These findings suggest that cold or drought environment conditions might be unfavorable for toxin production. Even so, some limitations, such as small sample sizes and deficient research, cannot be ignored.

Fusarium toxin contamination shows clear temporal dynamics; the epidemiologic degree of FHB has a clear relationship with the toxin contamination level. The occurrences of Fusarium toxins were studied in detail in Jiangsu, Anhui, and Henan provinces over a long period of time, and there was high concentration of Fusarium toxins over the standard rate in 1985, 1989, 1991, 2010, 2012, and 2015. This is an interesting discovery, as these unusual years were reported to have massive outbreaks of FHB, except for 1991, in which a large flood occurred. In 1985, Henan Province had the worst outbreak in 40 years; almost all the wheat grains were contaminated with DON, NIV, and ZEN in high amounts. The contamination rate for samples containing toxins higher than the tolerance limit of $1000 \mu \mathrm{g} / \mathrm{kg}$ was close to $50 \%$, and the highest number of DON-positive samples reached 40,000.0 $\mu \mathrm{g} / \mathrm{kg}$ [80]. In flour samples derived from wheat collected in 1989, the frequency of DON detection approached $100 \%$, and the average DON content was 1334.0 and $577.7 \mu \mathrm{g} / \mathrm{kg}$ in Anhui and Jiangsu, respectively [81,82]. There was an exceedingly high rate $(81.5 \%)$ of corresponding contamination in wheat, with a maximum concentration of $13,300.0 \mu \mathrm{g} / \mathrm{kg}$ [83]. In the last decade, the FHB epidemic has become more frequent and severe; moreover, toxin contamination, particularly by DON, is more common and serious. In 2010, 2012, and 2015, the average amounts of DON in Anhui wheat samples were 2701.0, 4501.6, and $17,753.8 \mu \mathrm{g} / \mathrm{kg}$, respectively [84-86]. The amounts in Jiangsu wheat samples in the corresponding years were $>1000.0,>3000.0$, and $>2000.0 \mu \mathrm{g} / \mathrm{kg}$, respectively [85,87-89]. FHB outbreaks aggravate toxin contamination despite the inconspicuous effect on ZEN accumulation.

Recently, masked DON, a derivative of DON, has become a focus of attention for in-depth research. D3G (deoxynivalenol-3-glucoside) is a primary type of masked DON and is the most studied. D3G was for the first time detected in naturally contaminated maize and wheat in 2005 [90]. Until now, the toxicological research about D3G is rare. As the protein synthesis inhibitor, the activity of D3G was much lower than that of DON [91]. Although there was no direct evidence that D3G was more toxic than its precursor, the existing research data showed that D3G could release DON by a hydrolysis reaction in the metabolic process [92-94]. Similar studies have raised concerns about the metabolites of D3G in humans or animals and the occurrence of this toxin in wheat grains and their products. A total of 192 wheat samples from 2007-2008 collected in 7 provinces were analyzed for D3G accumulation, and the toxin was found in $52.0 \%$ wheat samples with an average content of $43.0 \mu \mathrm{g} / \mathrm{kg}$ [95]. In a recent study, high incidence rates and levels of D3G were detected in wheat samples from Jiangsu and Anhui provinces in 2015-2016. A total of 96.3\% of wheat from Jiangsu was positive for D3G, with contamination rates ranging from 12.0 to $18061.0 \mu \mathrm{g} / \mathrm{kg}$ [89], while $99.5 \%$ of wheat from 
Anhui was contaminated by D3G, with contamination rates ranging from 28.3 to $2957.2 \mu \mathrm{g} / \mathrm{kg}$ [86]. The detection rate of D3G in wheat flour was to a certain degree, but the contamination level was obviously reduced. D3G was detected in 104/125 flour samples from 12 provinces $(0.1-52.8 \mu \mathrm{g} / \mathrm{kg})$ [96] and 38/158 wheat flour samples from 5 provinces $(8.7-33.3 \mu \mathrm{g} / \mathrm{kg}$ ) [97]. In 2010,33.4\% of Shandong wheat flour samples, $30.8 \%$ of Hubei wheat flour samples, and $5.46 \%$ of Hebei wheat flour samples contained D3G with average contamination rates of $1.1,<20.0$, and $1.9 \mu \mathrm{g} / \mathrm{kg}$, respectively [98-100]. During wheat processing, D3G was transferred to prepared products, such as bread and noodles, and caused toxic effects by producing DON after contact with intestinal digestive enzymes [101]. Thus, the fact that masked Fusarium toxins are also a potential risk to human health cannot be ignored.

From several national surveys, it was reported that multitoxin, mainly DON and ZEN, were widespread and severe in Chinese wheat grains, especially in the past decade. Although the overall contamination situation varied significantly in different years, wheat quality safety conditions increased in severity with the prevalence of FHB. The detection rate of Fusarium toxins in wheat flour remains at a certain level; nevertheless, most flour samples have toxin levels below Chinese regulatory limits and those of wheat grains. During wheat cleaning and flour milling, proper processing removes some toxins and is an effective measure in reducing toxin contamination. Considering the frequency and degree of the FHB epidemic, prolonged, successive, and extensive monitoring of Fusarium toxins in wheat and its products is essential for ensuring food safety and promoting human health. 
Table 4. Recent mycotoxin survey data in wheat grains in China.

\begin{tabular}{|c|c|c|c|c|c|c|c|c|}
\hline Year & Regions & Sample Sizes & Toxins & Incidence $(\%)$ & $\begin{array}{l}\text { Average Content } \\
(\mu \mathrm{g} / \mathrm{kg})\end{array}$ & Range ( $\mu \mathrm{g} / \mathrm{kg})$ & $\begin{array}{c}\text { Exceedance } \\
\text { Rate }(\%)\end{array}$ & Reference \\
\hline 1983 & \multirow{4}{*}{ Anhui } & 40 & \multirow{4}{*}{ DON } & 100.0 & 1161.4 & & 22.5 & \multirow{4}{*}{ [83] } \\
\hline 1986 & & 182 & & 44.5 & 312.9 & & 7.1 & \\
\hline 1989 & & 81 & & 100.0 & 2640.0 & $0-13,300.0$ & 81.5 & \\
\hline 1991 & & 26 & & 100.0 & 2105.8 & & 57.7 & \\
\hline \multirow{2}{*}{1986} & \multirow{2}{*}{ Anhui } & 150 & DON & 53.3 & 340.0 & $0-4000.0$ & & \multirow{2}{*}{ [102] } \\
\hline & & 83 & ZEN & 22.9 & 32.0 & $0-300.0$ & & \\
\hline 1991 & Anhui & 10 & DON & 100.0 & $15,900.0$ & $2000.0-50,000.0$ & 100.0 & [22] \\
\hline \multirow{6}{*}{ 2007-2008 } & \multirow{6}{*}{ Anhui } & \multirow{6}{*}{25} & D3G & 64.0 & 45.5 & $2.2-238.4$ & & \multirow{6}{*}{ [95] } \\
\hline & & & NIV & 72.0 & 53.3 & $1.8-229.9$ & & \\
\hline & & & 3ADON & 44.0 & 6.3 & $1.8-18.4$ & & \\
\hline & & & $15 \mathrm{ADON}$ & 12.0 & 2.6 & $2.3-3.0$ & & \\
\hline & & & DON & 100.0 & 46.3 & $3.7-169.3$ & 0 & \\
\hline & & & ZEN & 20.0 & 12.9 & $3.3-36.1$ & 0 & \\
\hline 2010 & Anhui & 21 & DON & 90.5 & 2701.0 & $521.0-4975.0$ & 81.0 & [84] \\
\hline 2012 & Anhui & 22 & DON & 95.4 & 4501.6 & $465.0-9930.0$ & & [85] \\
\hline \multirow{6}{*}{2015} & \multirow{6}{*}{ Anhui } & \multirow{6}{*}{370} & DON & 100.0 & $17,753.8$ & $109.6-86,255.1$ & & \multirow{6}{*}{ [86] } \\
\hline & & & D3G & 99.5 & 414.4 & $28.3-2957.2$ & & \\
\hline & & & NIV & 87.8 & 250.2 & $0-2399.7$ & & \\
\hline & & & $3 \mathrm{ADON}$ & 80.0 & 39.6 & $0-284.1$ & & \\
\hline & & & 15ADON & 67.3 & 13.2 & $0-184.7$ & & \\
\hline & & & ZEN & 68.7 & 25.7 & 0-1091.4 & 5.1 & \\
\hline
\end{tabular}


Table 4. Cont

\begin{tabular}{|c|c|c|c|c|c|c|c|c|}
\hline Year & Regions & Sample Sizes & Toxins & Incidence (\%) & $\begin{array}{c}\text { Average Content } \\
(\mu \mathrm{g} / \mathrm{kg})\end{array}$ & Range $(\mu \mathrm{g} / \mathrm{kg})$ & $\begin{array}{c}\text { Exceedance } \\
\text { Rate }(\%)\end{array}$ & Reference \\
\hline \multirow{2}{*}{1986} & \multirow{2}{*}{ Jiangsu } & 202 & $\mathrm{DON}$ & 26.7 & 40.0 & $0-400.0$ & 0 & \multirow{2}{*}{ [83] } \\
\hline & & 54 & ZEN & 64.8 & 51.0 & $0-300.0$ & & \\
\hline 1991 & Jiangsu & 7 & DON & 71.4 & 2900.0 & $1560.0-5000.0$ & & [23] \\
\hline \multirow{6}{*}{ 2007-2008 } & \multirow{6}{*}{ Jiangsu } & \multirow{6}{*}{24} & D3G & 62.5 & 59.3 & $1.7-179$ & & \multirow{6}{*}{ [95] } \\
\hline & & & NIV & 29.2 & 12.4 & $1.9-29.5$ & & \\
\hline & & & $3 \mathrm{ADON}$ & 29.2 & 5.5 & $2.1-11.3$ & & \\
\hline & & & $15 \mathrm{ADON}$ & 4.2 & 2.4 & $0-2.4$ & & \\
\hline & & & DON & 95.8 & 73.0 & $2.8-408.3$ & 0 & \\
\hline & & & ZEN & 16.7 & 3.9 & $1.7-6.6$ & 0 & \\
\hline 2010 & Jiangsu & 35 & DON & 88.6 & 1221.0 & $259.0-3900.0$ & 51.4 & [84] \\
\hline \multirow{2}{*}{2010} & \multirow{6}{*}{ Jiangsu } & \multirow{2}{*}{41} & DON & 100.0 & 1075.2 & $151.6-2550.2$ & 44.0 & \multirow{6}{*}{ [87] } \\
\hline & & & ZEN & 46.3 & 216.0 & $10.1-3048.9$ & 9.8 & \\
\hline \multirow{2}{*}{2011} & & \multirow{2}{*}{64} & DON & 32.8 & 82.1 & $14.5-1579.8$ & 3.1 & \\
\hline & & & ZEN & 0 & 0 & 0 & 0 & \\
\hline \multirow{2}{*}{2012} & & \multirow{2}{*}{75} & DON & 96.0 & 306.7 & $16.3-41157.1$ & 48.0 & \\
\hline & & & ZEN & 5.3 & 3.2 & $50.2-72.6$ & 2.6 & \\
\hline 2012 & Jiangsu & 62 & DON & 95.1 & 3260.9 & $260.0-11,200.0$ & & [85] \\
\hline 2013 & \multirow{3}{*}{ Jiangsu } & 66 & \multirow{3}{*}{ ZEN } & 37.9 & 11.8 & $6.5-110.0$ & & \multirow{3}{*}{ [88] } \\
\hline 2014 & & 66 & & 46.9 & 22.0 & $15.0-194.3$ & & \\
\hline 2015 & & 70 & & 54.3 & 39.3 & $25.1-307.3$ & & \\
\hline \multirow{2}{*}{2015} & \multirow{4}{*}{ Jiangsu } & \multirow{2}{*}{443} & DON & 100.0 & 2087.0 & $166.0-14,960.0$ & & \multirow{4}{*}{ [89] } \\
\hline & & & D3G & 96.0 & 545.0 & $83.0-5092.0$ & & \\
\hline \multirow{2}{*}{2016} & & \multirow{2}{*}{439} & DON & 100.0 & 2601.0 & $12.0-18,061.0$ & & \\
\hline & & & D3G & 97.0 & 819.0 & $0-6708.0$ & & \\
\hline
\end{tabular}


Table 4. Cont

\begin{tabular}{|c|c|c|c|c|c|c|c|c|}
\hline Year & Regions & Sample Sizes & Toxins & Incidence (\%) & $\begin{array}{c}\text { Average Content } \\
(\mu \mathrm{g} / \mathrm{kg})\end{array}$ & Range $(\mu \mathrm{g} / \mathrm{kg})$ & $\begin{array}{c}\text { Exceedance } \\
\text { Rate }(\%)\end{array}$ & Reference \\
\hline \multirow{2}{*}{1985} & \multirow{2}{*}{ Henan } & \multirow{2}{*}{19} & DON & 100.0 & $17,500.0$ & $1.0-40,000.0$ & 100.0 & \multirow{2}{*}{ [17] } \\
\hline & & & ZEN & 10.5 & 375.0 & $250.0-500.0$ & 10.5 & \\
\hline \multirow{3}{*}{1985} & \multirow{3}{*}{ Henan } & 191 & DON & 99.0 & 923.0 & $15.9-3337.8$ & 47.1 & \multirow{5}{*}{ [80] } \\
\hline & & 191 & NIV & 81.0 & 128.2 & $12.5-608.6$ & & \\
\hline & & 92 & ZEN & 100.0 & 15.3 & $3.3-149.9$ & & \\
\hline \multirow{2}{*}{1986} & \multirow{2}{*}{ Henan } & \multirow{2}{*}{100} & DON & 74.0 & 14.2 & $6.7-175.4$ & 0 & \\
\hline & & & NIV & 4.0 & & $9.5-49.0$ & & \\
\hline \multirow{2}{*}{1986} & \multirow{2}{*}{ Henan } & 97 & $\mathrm{DON}$ & 57.7 & 40.0 & $0-400.0$ & 0 & \multirow{2}{*}{ [102] } \\
\hline & & 60 & ZEN & 11.7 & 8.0 & $0-50.0$ & 0 & \\
\hline 1991 & Henan & 35 & $\mathrm{DON}$ & 100.0 & 1500.0 & $1000.0-3500.0$ & 100.0 & [23] \\
\hline 1991 & Henan & 24 & DON & & & $0-3500.0$ & 41.7 & [103] \\
\hline \multirow{8}{*}{1998} & \multirow{12}{*}{ Henan } & \multirow{4}{*}{31} & DON & 96.8 & 2850.0 & $177.0-14,000.0$ & & \multirow{12}{*}{ [29] } \\
\hline & & & $15 \mathrm{ADON}$ & 64.5 & 365.0 & $59.0-1800.0$ & & \\
\hline & & & NIV & 3.2 & 578.0 & $0-578.0$ & & \\
\hline & & & ZEN & 67.7 & 209.0 & $9.0-1400.0$ & & \\
\hline & & \multirow{4}{*}{28} & DON & 89.3 & 223.0 & $53.0-1240.0$ & & \\
\hline & & & $15 \mathrm{ADON}$ & 0 & 0 & 0 & & \\
\hline & & & NIV & 0 & 0 & 0 & & \\
\hline & & & ZEN & 25.0 & 108.0 & $1.0-217.0$ & & \\
\hline \multirow{4}{*}{1999} & & \multirow{4}{*}{34} & $\mathrm{DON}$ & 85.3 & 294.0 & $74.0-941.0$ & 0 & \\
\hline & & & 15ADON & 0 & 0 & 0 & & \\
\hline & & & NIV & 0 & 0 & 0 & & \\
\hline & & & ZEN & 58.8 & 23.0 & $5.0-113.0$ & & \\
\hline
\end{tabular}


Table 4. Cont

\begin{tabular}{|c|c|c|c|c|c|c|c|c|}
\hline Year & Regions & Sample Sizes & Toxins & Incidence (\%) & $\begin{array}{c}\text { Average Content } \\
(\mu \mathrm{g} / \mathrm{kg})\end{array}$ & Range $(\mu \mathrm{g} / \mathrm{kg})$ & $\begin{array}{c}\text { Exceedance } \\
\text { Rate }(\%)\end{array}$ & Reference \\
\hline \multirow{6}{*}{ 2007-2008 } & \multirow{6}{*}{ Henan } & \multirow{6}{*}{28} & D3G & 75.0 & 24.6 & $2.8-171.1$ & & \multirow{6}{*}{ [95] } \\
\hline & & & NIV & 0 & 0 & 0 & & \\
\hline & & & 3ADON & 14.3 & 3.6 & $0-4.9$ & & \\
\hline & & & $15 \mathrm{ADON}$ & 46.4 & 4.1 & $0-17.7$ & & \\
\hline & & & DON & 100.0 & 74.6 & $2.9-363.6$ & 0 & \\
\hline & & & ZEN & 17.9 & 3.3 & $0-8.1$ & 0 & \\
\hline \multirow{2}{*}{1986} & \multirow{2}{*}{ Shanghai } & \multirow{2}{*}{100} & DON & 100.0 & 340.0 & 0-2000.0 & & \multirow{2}{*}{ [102] } \\
\hline & & & ZEN & 33.0 & 11.0 & $0-780.0$ & & \\
\hline \multirow{2}{*}{1995} & \multirow{2}{*}{ Shanghai } & \multirow{2}{*}{100} & $\mathrm{DON}$ & 53.0 & 280.9 & 0-1919.7 & 10.0 & \multirow{2}{*}{ [104] } \\
\hline & & & NIV & 35.0 & 103.4 & $0-1428.0$ & & \\
\hline 2009-2012 & Shanghai & 198 & DON & 80.8 & 64.7 & $0.5-604.0$ & 0 & \multirow{3}{*}{ [105] } \\
\hline \multirow{2}{*}{ 2011-2012 } & \multirow{2}{*}{ Shanghai } & \multirow{2}{*}{38} & $3 \mathrm{ADON}$ & 100.0 & 10.3 & $0.7-35.2$ & & \\
\hline & & & 15-DON & 100.0 & 1.4 & $0.5-6.2$ & & \\
\hline \multirow{6}{*}{$2007-2008$} & \multirow{6}{*}{ Hebei } & \multirow{6}{*}{25} & D3G & 60.0 & 88.9 & $5.6-388.0$ & & \multirow{6}{*}{ [95] } \\
\hline & & & NIV & 24.0 & 12.3 & $1.8-57.5$ & & \\
\hline & & & $3 \mathrm{ADON}$ & 48.0 & 12.5 & $1.6-70.8$ & & \\
\hline & & & $15 \mathrm{ADON}$ & 88.0 & 236.1 & $1.5-1256.2$ & & \\
\hline & & & DON & 80.0 & 167.3 & $1.7-636.2$ & 0 & \\
\hline & & & ZEN & 56.0 & 126.1 & $4.7-930.4$ & & \\
\hline \multirow{2}{*}{1986} & \multirow{2}{*}{ Gansu } & 135 & $\mathrm{DON}$ & 57.0 & 2050.0 & $0-20,000.0$ & & \multirow{2}{*}{ [102] } \\
\hline & & 101 & ZEN & 40.6 & 15.0 & $0-300.0$ & & \\
\hline \multirow{4}{*}{2013} & Shannxi & 81 & \multirow{4}{*}{ DON } & 96.1 & 515.3 & $79.0-3030.0$ & 8.64 & \multirow{4}{*}{ [106] } \\
\hline & Ningxia & 26 & & 100.0 & 804.4 & $71.0-2330.0$ & 26.92 & \\
\hline & Gansu & 52 & & 86.5 & 294.4 & $0-1798.0$ & 1.92 & \\
\hline & Xinjiang & 22 & & 0 & 0 & 0 & 0 & \\
\hline
\end{tabular}


Table 4. Cont

\begin{tabular}{|c|c|c|c|c|c|c|c|c|}
\hline Year & Regions & Sample Sizes & Toxins & Incidence (\%) & $\begin{array}{c}\text { Average Content } \\
(\mu \mathrm{g} / \mathrm{kg})\end{array}$ & Range $(\mu \mathrm{g} / \mathbf{k g})$ & $\begin{array}{c}\text { Exceedance } \\
\text { Rate }(\%)\end{array}$ & Reference \\
\hline \multirow{2}{*}{ 2000-2016 } & \multirow{2}{*}{ Tibet } & \multirow{2}{*}{199} & DON & 0 & 0 & 0 & 0 & \multirow{2}{*}{ [77] } \\
\hline & & & ZEN & 0.5 & & & 0.5 & \\
\hline \multirow{6}{*}{ 2007-2008 } & \multirow{6}{*}{ Sichuan } & \multirow{6}{*}{30} & D3G & 0 & 0 & 0 & & \multirow{6}{*}{ [95] } \\
\hline & & & NIV & 73.3 & 17.7 & $3.0-39.1$ & & \\
\hline & & & $3 \mathrm{ADON}$ & 0 & 0 & 0 & & \\
\hline & & & $15 \mathrm{ADON}$ & 0 & 0 & 0 & & \\
\hline & & & DON & 50.0 & 16.4 & $3.0-47.8$ & 0 & \\
\hline & & & ZEN & 20.0 & 5.1 & $2.0-8.8$ & 0 & \\
\hline \multirow{6}{*}{ 2007-2008 } & \multirow{6}{*}{ Chongqing } & \multirow{6}{*}{30} & D3G & 73.3 & 72.5 & $9.8-235.3$ & & \multirow{6}{*}{ [95] } \\
\hline & & & NIV & 100.0 & 199.5 & $7.8-1035.8$ & & \\
\hline & & & $3 \mathrm{ADON}$ & 60.0 & 9.1 & $1.9-34.6$ & & \\
\hline & & & $15 \mathrm{ADON}$ & 46.7 & 9.6 & $2.1-71.0$ & & \\
\hline & & & DON & 100.0 & 133.3 & $12.0-590.7$ & 0 & \\
\hline & & & ZEN & 80.0 & 199.4 & $2.3-3425.1$ & & \\
\hline 2016 & Heilongjiang & 55 & DON & 0 & 0 & 0 & 0 & [59] \\
\hline \multirow{3}{*}{1984} & \multirow{3}{*}{ China } & \multirow{3}{*}{29} & $\mathrm{DON}$ & 51.7 & 401.7 & $0-2450.0$ & 6.9 & \multirow{3}{*}{ [107] } \\
\hline & & & NIV & 37.9 & 267.3 & $0-6644.0$ & & \\
\hline & & & ZEN & 44.8 & 6.8 & $0-32.0$ & 0 & \\
\hline 2003 & China & 48 & ZEN & 100.0 & 98.0 & $0-470.0$ & 72.9 & [108] \\
\hline 2005 & China & 190 & DON & 66.3 & 50.0 & $0-612.7$ & 0 & [109] \\
\hline \multirow{2}{*}{2007} & \multirow{2}{*}{ China } & \multirow{2}{*}{229} & DON & 38.0 & 73.9 & $0-600.8$ & 0 & \multirow{2}{*}{ [110] } \\
\hline & & & ZEN & 16.0 & 1.6 & $0-72.4$ & & \\
\hline \multirow{2}{*}{2008} & \multirow{2}{*}{ China } & \multirow{2}{*}{41} & DON & 97.6 & 425.5 & & 9.8 & \multirow{2}{*}{ [111] } \\
\hline & & & ZEN & 68.3 & 152.4 & & 41.5 & \\
\hline \multirow{2}{*}{ 2010-2013 } & \multirow{2}{*}{ China } & \multirow{2}{*}{681} & DON & 66.5 & 72.8 & 774.8-14276.0 & & \multirow{2}{*}{ [112] } \\
\hline & & & AcDON & 66.8 & 74.7 & 797.7-14604.2 & & \\
\hline
\end{tabular}


Table 5. Recent mycotoxin survey data in wheat flour in China.

\begin{tabular}{|c|c|c|c|c|c|c|c|c|}
\hline Year & Regions & Toxins & Sample Sizes & Incidence (\%) & $\begin{array}{c}\text { Average Content } \\
(\mu \mathrm{g} / \mathrm{kg})\end{array}$ & $\begin{array}{l}\text { Range } \\
(\mu \mathrm{g} / \mathrm{kg})\end{array}$ & $\begin{array}{c}\text { Exceedance } \\
\text { Rate (\%) }\end{array}$ & Reference \\
\hline 1983-1991 & Anhui & DON & 132 & 92.4 & 1065.6 & & 40.9 & [83] \\
\hline 1988 & Hebei & DON & 50 & 54.0 & 75.0 & $0-173.0$ & 0 & [113] \\
\hline 1988-1989 & Anhui & DON & 100 & 90.0 & 1008.6 & & 43.0 & [114] \\
\hline \multirow{2}{*}{ 1988-1989 } & \multirow{2}{*}{ Shanghai } & \multirow{2}{*}{ DON } & 25 & 100.0 & 79.8 & & 0 & \multirow{2}{*}{ [115] } \\
\hline & & & 25 & 80.0 & 58.1 & & 0 & \\
\hline 1989 & Anhui & DON & 84 & 100.0 & 1334.0 & & 58.3 & [81] \\
\hline 1989 & Jiangsu & DON & 50 & 96.0 & 577.7 & & 18.0 & [82] \\
\hline \multirow{2}{*}{1996} & \multirow{2}{*}{ Shanghai } & DON & \multirow{2}{*}{30} & 86.7 & 101.2 & & 0 & \multirow{2}{*}{ [104] } \\
\hline & & NIV & & 56.7 & 53.3 & & & \\
\hline \multirow{3}{*}{2009} & \multirow{3}{*}{$\begin{array}{c}\text { China } \\
\text { (13 provinces) }\end{array}$} & DON & \multirow{3}{*}{292} & 100.0 & 178.4 & $0.5-2995.1$ & 1.7 & \multirow{3}{*}{ [116] } \\
\hline & & ZEN & & 53.4 & 5.1 & $0.3-55.0$ & 0 & \\
\hline & & NIV & & 88.4 & 8.1 & $0.3-218.2$ & & \\
\hline \multirow{6}{*}{2010} & \multirow{6}{*}{$\begin{array}{c}\text { China } \\
\text { (12 provinces) }\end{array}$} & DON & \multirow{6}{*}{125} & 96.8 & 179.0 & $0.1-1016.8$ & 0.8 & \multirow{6}{*}{ [96] } \\
\hline & & $3 \mathrm{ADON}$ & & 64.0 & 2.2 & $0.1-19.8$ & & \\
\hline & & $15 \mathrm{ADON}$ & & 95.2 & 4.2 & $0.1-25.5$ & & \\
\hline & & D3G & & 83.2 & 10.1 & $0.1-52.8$ & & \\
\hline & & NIV & & 86.4 & 10.3 & $0.1-76.5$ & & \\
\hline & & ZEN & & 72.8 & 3.5 & $0.1-52$ & 0 & \\
\hline 2010 & \multirow{4}{*}{$\begin{array}{c}\text { China } \\
\text { (28 provinces) }\end{array}$} & \multirow{4}{*}{ DON } & & & 143.0 & & 4.2 & \multirow{4}{*}{ [117] } \\
\hline 2011 & & & & & 147.0 & & 2.2 & \\
\hline 2012 & & & & & 658.0 & & 20.7 & \\
\hline 2013 & & & 5678 & 58.7 & 317.0 & $0-56,100$ & 4.7 & \\
\hline
\end{tabular}


Table 5. Cont.

\begin{tabular}{|c|c|c|c|c|c|c|c|c|}
\hline Year & Regions & Toxins & Sample Sizes & Incidence (\%) & $\begin{array}{c}\text { Average Content } \\
(\mu \mathrm{g} / \mathrm{kg})\end{array}$ & $\begin{array}{l}\text { Range } \\
(\mu \mathrm{g} / \mathrm{kg})\end{array}$ & $\begin{array}{c}\text { Exceedance } \\
\text { Rate }(\%)\end{array}$ & Reference \\
\hline \multirow{2}{*}{ 2010-2013 } & \multirow{2}{*}{ China } & DON & 3848 & 71.7 & 126.0 & $218.0-6922.0$ & & \multirow{2}{*}{ [112] } \\
\hline & & AcDON & 3860 & 71.8 & 91.5 & $219.2-6922.0$ & & \\
\hline \multirow{6}{*}{ 2010- } & \multirow{6}{*}{ Shandong } & DON & \multirow{6}{*}{359} & 97.2 & 84.3 & $0-825.9$ & 0 & \multirow{6}{*}{ [98] } \\
\hline & & $3 \mathrm{ADON}$ & & 11.1 & 0.1 & $0-3.6$ & & \\
\hline & & $15 \mathrm{ADON}$ & & 14.2 & 0.5 & $0-11.1$ & & \\
\hline & & NIV & & 40.4 & 1.4 & $0-23.9$ & & \\
\hline & & D3G & & 33.4 & 1.1 & $0-15.7$ & & \\
\hline & & ZEN & & 0 & 0 & 0 & 0 & \\
\hline \multirow{2}{*}{ 2010- } & \multirow{2}{*}{ Hubei } & DON & \multirow{2}{*}{26} & 69.2 & 129.4 & $0-2133.2$ & 3.9 & \multirow{2}{*}{ [99] } \\
\hline & & D3G & & 30.8 & $<20.0$ & $0-252.4$ & & \\
\hline \multirow{6}{*}{$2010-$} & \multirow{6}{*}{ Hebei } & DON & \multirow{6}{*}{348} & 91.4 & 240.0 & $0-1129.0$ & 0.6 & \multirow{6}{*}{ [100] } \\
\hline & & $15 \mathrm{ADON}$ & & 34.2 & 1.9 & $0-6.0$ & & \\
\hline & & NIV & & 16.4 & 3.2 & $0-19.1$ & & \\
\hline & & ZEN & & 13.2 & 8.4 & $0-98.8$ & 0.3 & \\
\hline & & D3G & & 5.5 & 1.9 & $0-3.9$ & & \\
\hline & & $3 \mathrm{ADON}$ & & 2.1 & 3.2 & $0-2.6$ & & \\
\hline \multirow{3}{*}{2011} & \multirow{9}{*}{ Hebei } & DON & \multirow{3}{*}{31} & 16.1 & 137.0 & $2.4-639.0$ & 0 & \multirow{9}{*}{ [118] } \\
\hline & & $3 \mathrm{ADON}$ & & 6.4 & 0.7 & $0.6-0.8$ & & \\
\hline & & $15 \mathrm{ADON}$ & & 0 & 0 & & & \\
\hline \multirow{3}{*}{2012} & & DON & \multirow{3}{*}{348} & 91.4 & 240.0 & $11.5-1130.0$ & 0.6 & \\
\hline & & $3 \mathrm{ADON}$ & & 34.2 & 1.9 & $1.1-6.0$ & & \\
\hline & & $15 \mathrm{ADON}$ & & 3.2 & 2.1 & $1.5-2.6$ & & \\
\hline \multirow{3}{*}{2013} & & DON & \multirow{3}{*}{293} & 99.6 & 156.0 & $6.2-878.0$ & 0 & \\
\hline & & $3 \mathrm{ADON}$ & & 0 & 0 & 0 & & \\
\hline & & $15 \mathrm{ADON}$ & & 0 & 0 & 0 & & \\
\hline
\end{tabular}


Table 5. Cont.

\begin{tabular}{|c|c|c|c|c|c|c|c|c|}
\hline Year & Regions & Toxins & Sample Sizes & Incidence (\%) & $\begin{array}{c}\text { Average Content } \\
(\mu \mathrm{g} / \mathrm{kg})\end{array}$ & $\begin{array}{l}\text { Range } \\
(\mu \mathrm{g} / \mathrm{kg})\end{array}$ & $\begin{array}{c}\text { Exceedance } \\
\text { Rate (\%) }\end{array}$ & Reference \\
\hline 2013 & $\begin{array}{c}\text { China } \\
\text { (10 provinces) }\end{array}$ & DON & 50 & 30.0 & 58.1 & $0-862.0$ & 0 & [119] \\
\hline \multirow{6}{*}{2013} & \multirow{6}{*}{$\begin{array}{c}\text { China } \\
\text { (5 provinces) }\end{array}$} & DON & \multirow{6}{*}{158} & 84.2 & 4084.8 & $23.5-25,375$ & 68.0 & \multirow{6}{*}{ [97] } \\
\hline & & D3G & & 24.1 & 13.9 & $8.7-33.3$ & & \\
\hline & & $3 \mathrm{ADON}$ & & 84.2 & 14.9 & $10.6-177.5$ & & \\
\hline & & $15 \mathrm{ADON}$ & & 60.8 & 14.7 & $13.4-23.5$ & & \\
\hline & & NIV & & 22.2 & 26.9 & $1.8-94.0$ & & \\
\hline & & ZEN & & 77.2 & 85.8 & $13-158$ & 24.0 & \\
\hline \multirow{2}{*}{2013} & \multirow{2}{*}{ Fujian } & $\mathrm{DON}$ & \multirow{2}{*}{59} & 89.8 & & & 11.2 & \multirow{2}{*}{ [120] } \\
\hline & & ZEN & & 11.9 & & & 0 & \\
\hline 2013 & Guangdong & DON & 30 & 86.7 & 87.9 & $0-860.8$ & 0 & [121] \\
\hline \multirow{4}{*}{ 2013-2016 } & \multirow{4}{*}{ Shannxi } & $\mathrm{DON}$ & \multirow{4}{*}{504} & 86.9 & 311.0 & $6.0-3670.0$ & 6.7 & \multirow{4}{*}{ [122] } \\
\hline & & $3 \mathrm{ADON}$ & & 59.9 & 33.7 & $21.9-535.0$ & & \\
\hline & & $15 \mathrm{ADON}$ & & 8.3 & 5.7 & $4.5-105.0$ & & \\
\hline & & ZEN & & 0.2 & 2.6 & $0-31.0$ & 0 & \\
\hline \multirow{2}{*}{2013} & \multirow{2}{*}{ Tibet } & DON & \multirow{2}{*}{85} & 27.1 & 47.0 & $0-630.0$ & 0 & \multirow{2}{*}{ [78] } \\
\hline & & ZEN & & 74.0 & 5.4 & $0-13.9$ & 0 & \\
\hline \multirow{2}{*}{2014} & \multirow{2}{*}{ Xinjiang } & DON & \multirow{2}{*}{84} & 51.2 & 20.3 & $8.7-152.6$ & 0 & \multirow{2}{*}{ [79] } \\
\hline & & $15 \mathrm{ADON}$ & & 28.6 & 15.3 & $5.6-159.2$ & & \\
\hline 2014 & Henan & DON & 65 & 69.2 & 218.3 & & 0 & [123] \\
\hline 2014 & Hebei & DON & 293 & 99.7 & 156.0 & $0-878.4$ & 0 & [124] \\
\hline \multirow{4}{*}{ 2014-2015 } & \multirow{4}{*}{ Henan } & $\mathrm{DON}$ & \multirow{4}{*}{295} & 8.8 & 14.4 & $0-750.0$ & 0 & \multirow{4}{*}{ [125] } \\
\hline & & $3 \mathrm{ADON}$ & & 0 & 0 & 0 & 0 & \\
\hline & & $15 \mathrm{ADON}$ & & 0 & 0 & 0 & 0 & \\
\hline & & ZEN & & 0 & 0 & 0 & 0 & \\
\hline
\end{tabular}


Table 5. Cont

\begin{tabular}{|c|c|c|c|c|c|c|c|c|}
\hline Year & Regions & Toxins & Sample Sizes & Incidence (\%) & $\begin{array}{l}\text { Average Content } \\
(\mu \mathrm{g} / \mathrm{kg})\end{array}$ & $\begin{array}{l}\text { Range } \\
(\mu \mathrm{g} / \mathrm{kg})\end{array}$ & $\begin{array}{c}\text { Exceedance } \\
\text { Rate }(\%)\end{array}$ & Reference \\
\hline \multirow{8}{*}{ 2016-2017 } & \multirow{8}{*}{ Jiangsu } & $\mathrm{DON}$ & \multirow{4}{*}{35} & 100.0 & 308.9 & $44.6-924.6$ & 0 & \multirow{8}{*}{ [126] } \\
\hline & & 3ADON & & 28.6 & 7.1 & $0-54.9$ & & \\
\hline & & 15ADON & & 17.1 & 3.2 & $0-23.7$ & & \\
\hline & & ZEN & & 17.1 & 1.2 & $0-16.9$ & 0 & \\
\hline & & $\mathrm{DON}$ & \multirow{4}{*}{50} & 62.0 & 91.9 & $0-401.8$ & 0 & \\
\hline & & $3 \mathrm{ADON}$ & & 6.0 & 1.1 & $0-21.0$ & & \\
\hline & & $15 \mathrm{ADON}$ & & 2.0 & 0.3 & $0-14.7$ & & \\
\hline & & ZEN & & 0 & 0 & 0 & 0 & \\
\hline \multirow{2}{*}{2017} & \multirow{2}{*}{ China } & \multirow{2}{*}{ DON } & 75 & 85.3 & 455.7 & $12.5-1285.4$ & 20.0 & \multirow{2}{*}{ [127] } \\
\hline & & & 15 & 100.0 & 426 & 51.6-1308.9 & 13.3 & \\
\hline
\end{tabular}




\section{Fusarium Toxin Management}

Since FHB can lead to economic losses and health concerns, some comprehensive strategies for the reduction in the occurrence of FHB and Fusarium mycotoxins need to be developed. A combination of planting resistant cultivars, adapting agricultural practices, and applying chemical and biological controls for reducing fungi invasion and toxin production may help to control the occurrence of FHB and its associated mycotoxins.

\subsection{Expansion of the Basic Knowledge about Toxin Production}

Similar to pigments and antibiotics, Fusarium toxins are secondary metabolites produced by Fusarium species during its natural growth; these metabolites are closely associated with cell differentiation, growth, and the response to the external environment. Successful whole genome sequencing of several Fusarium species has provided useful data for researchers to study the biosynthesis pathways and regulatory mechanisms of mycotoxins [128] and has led to the complete resolution of the trichothecene gene cluster (TRI-cluster) $[129,130]$ and zearalenone biosynthetic gene cluster [131,132]. Environmental factors, including pH [133,134], carbon sources [135], nitrogen sources [136,137], $\mathrm{H}_{2} \mathrm{O}_{2}$ [138], availability of free water $\left(\mathrm{a}_{\mathrm{w}}\right)$, incubation temperatures [139] and regulatory signaling pathways, including the mitogen-activated protein kinase (MAPK) [140], cyclic adenosine phosphate-protein kinase A (cAMP-PKA) [141,142], and target of rapamycin (TOR) pathways [143], can influence toxin accumulation. These molecular mechanisms offer targets for the inhibition of DON synthesis by genetic engineering technology.

Several studies on detailed species and chemotype identification, population genetic diversity, and biological characteristics of FHB pathogens from wheat in China have been performed $[60,66,144]$. $3 \mathrm{ADON}$-producing populations with high toxin accumulation are more dominant. The identification of advantageous populations, temporal dynamics evolution trends and ecological adaptations could provide a theoretical basis for confirming a regulatory focus, breeding for FHB resistance, and developing targeted disease and mycotoxin control strategies.

\subsection{Maturation of Chemical Control Measure of FHB}

Spraying carbendazim during the wheat flowering period is a common method for controlling FHB and has played a crucial role in integrated disease control programs since the 1970s. However, the monitoring results of Fusarium toxins in wheat samples calls into question the true effects of chemical control on toxin production. In the past, control was measured only by the decrease in the visual disease index and the recovery of economic losses; serious toxin contamination was largely ignored. As such, the efficacy of carbendazim on toxin accumulation is questionable. Poor reductions in toxin accumulation may be due to the increase in Fusarium species that are resistant to carbendazim and the improved synthesis ability of DON in resistant strains compared with that of conventional strains $[145,146]$. High doses of the fungicide and the high proportion of resistant strains in the field may be associated with the serious toxin contamination in wheat samples from Jiangsu and Anhui provinces. In some regions with low carbendazim resistance, this compound can still reduce the disease index, diseased kernel rate and DON content remarkably [147].

Phenamacril, a new type of acrylate fungicide, was developed by China; phenamacril provides successful control of a variety of plant diseases caused by Fusarium. Field experiments indicated that phenamacril showed better efficacy against FHB than carbendazim, and the yield increase effect was equivalent to that of carbendazim [146]. Moreover, the application of phenamacril reduced the total DON level in wheat grains by more than $80 \%$ compared with the untreated controls, and phenamacril exhibited great potential in toxin management $[147,148]$. Currently, this fungicide has been popularized and applied in most wheat-growing areas. 
Another kind of fungicide that can significantly reduce the ability of pathogens to infect plants and synthesize toxins is the azole antifungals, including metconazole, propiconazole, prothioconazole, and tebuconazole, which belong to the class of demethylation inhibitors. Several studies have proved that tebuconazole alone at varied concentrations or in combination with other fungicides was effective in inhibiting FHB and DON, and the drug showed optimal performance at the early anthesis stage or later anthesis stage [147-150]. The sensitivities of FHB pathogens to metconazole and the efficacy of this fungicide in FHB and DON control in China were reported in a recent study; metconazole exhibited better efficacy than phenamacril and carbendazim [151]. Propiconazole also had a certain role in toxin management [148], but it was reported that this fungicide may have the opposite effect on toxin control at low doses. Sublethal doses of propiconazole triggered $\mathrm{H}_{2} \mathrm{O}_{2}$ production in vitro and further induced DON accumulation in the pathogen [152].

According to a new study, validamycin, a type of fungicide for the control of crop diseases caused by Rhizoctonia species, had a remarkable effect on reducing DON synthesis by F. graminearum $[153,154]$. Further research on the molecular mechanism revealed that validamycin decreased glucose production by targeting trehalase and blocking the glycolytic pathway, thereby reducing pyruvate and DON production [153]. This finding provides us with important reference values and guidance in the screening of appropriate fungicides against harmful metabolites, as no fungicidal activity of validamycin against $F$. graminearum was discovered in vitro.

There are many agricultural practices to combat pathogens, diseases, and contaminants; however, chemical control is still the most powerful and effective measure. The effect of fungicides on mycotoxins is complicated and can be influenced by various factors, such as toxin-producing fungus, environmental conditions, and treatment dosage. More research on the mechanisms of toxin production and compound mode of action is needed to provide theoretical support for the scientific and reasonable use of fungicides. Chinese government is vigorously implementing the strategy of the dosage reduction and efficiency increase of chemical pesticides, as pesticide residue is a threat to food safety and cannot be ignored. More rational and efficient application of these substances is extremely essential.

\subsection{Development of Process Control Technology}

Wheat can experience a serious loss of tissue composition after infection with scab, resulting in a change in the wheat kernel appearance. Diseased grains usually have shriveled surfaces, declined particle diameters, decreased hardness, and decreased weight; therefore, specific gravity separation is the best method to remove infected wheat kernels before storage and processing. Historically, wind force was used to separate diseased and normal grains based on simple devices, and notable results were obtained. Liang et al. [155] suggested that DON content could be effectively controlled by removing scabby grains with wind and sifting. More recently, a specific gravity separator combined with winnower has played an important role in wheat cleaning and purification. Li et al. [156] conducted particle size and specific gravity separation of raw material and found the redistribution of DON samples. After the elimination of impurities and infected grains, edible wheat was obtained with a $68.94 \%$ decrease in total DON compared with the level of DON in the original samples. Bian et al. [157] and Zhu et al. [158] further improved the conventional gravity separation technology; the mass fraction for the DON-contaminated fraction increased while the proportion decreased, indicating that the improved technology effectively and efficiently discarded DON-contaminated wheat grains. 
It is well known that scabby wheat kernels present different shades of red due to the infection of Fusarium, and electric color sorting technology based on color characteristics can separate the contaminated grains to effectively manage toxins. The soft independent modelling of class analogies (SIMCA) model based on near infrared spectrum and hyperspectral imaging technology has been successfully applied in the identification of scabby grains and DON levels, with a recognition accuracy above 90\% [159-161]. Shen et al. [162] established quantitative models for DON with attenuated total reflectance-Fourier transform infrared spectroscopy (ATR-FTIR) and developed a method for the rapid determination of DON in wheat and its products by associating the absorption values of samples with various DON contents with different bands. With the combined gravity and color sorting technology and equipment in the cleaning process, the DON content decreased from $1.56 \mathrm{mg} / \mathrm{kg}$ to $1.18 \mathrm{mg} / \mathrm{kg}$ [163].

Cleaning is the first step in wheat processing and plays a vital role in wheat flour safety. At present, color and gravity sorters have been implemented in most flour milling enterprises and are of great importance to mycotoxin reduction and the quality improvement of wheat flour and its products.

\subsection{Improvement of the Standard System}

To protect public health from the negative impacts of Fusarium toxins, many countries and food safety regulators, including China, have introduced maximum or recommended toxin levels for food and feed. Specific regulations at the national level are released by authoritative bodies (Table 6). The former National Health and Family Planning Commission (NHFPC) and China Food and Drug Administration (CFDA) jointly issued national food safety standards (GB 2761-2017), in which the main mycotoxin limits of food were specified. The regulatory limits of mycotoxins in the revised national food safety standards in the infant formula (GB 10765), older infant formula (GB10766), young children (GB 10767), and raw milk (GB 19301-2010) general rules for aged-food (draft for comments) were determined to be in accordance with GB 2761. The former General Administration of Quality Supervision, Inspection and Quarantine of the People's Republic of China (AQSIQ) and Standardization Administration of China (SAC) promulgated hygienic standards for feed (GB 13078) and fully stipulated limit values for toxicants in feedstuffs and products. These standards help the government protect the of health citizens through food safety guarantees. As technical barriers in international trade, they may also contribute to the protection of domestic markets and industry development.

The national standard system of mycotoxin detection has been improved (Table 7), and some detection standards provide technical support for agricultural product quality and safety supervision, particularly for the most advanced analytical instruments, such high-performance liquid chromatography (HPLC), ultraperformance liquid chromatography (UPLC), and high-performance liquid chromatography-tandem mass spectrometry (HPLC-MS/MS). This progression reflects the level of technological innovation in the application and promotion of standards.

However, safety and detection standard systems for agriculture products are in some developing countries and regions are still incomplete. China focuses mostly on primary agricultural products, and agro-products from varied processes for different purposes and consumer bases lack specific standards. For instance, there are no specific rules for direct consumables. Moreover, the process of establishing standards is slightly behind. China does not have established maximum levels for D3G, NIV, and other common toxins. As for minor crops, most lack limitation standards and related testing standards. Combined contamination of multitoxin is a common feature of cereal grains, and a standard for the simultaneous determination of multitoxin is a top research priority. 


\section{Conclusions and Challenges for the Future}

In the present review, we gathered available Chinese data from the last half century on the occurrence of Fusarium species and toxins in wheat as well as the resultant food-poisoning incidents. Because of climatic conditions and cropping systems, there are increased amounts of infection sources and greater risks of FHB epidemics and Fusarium toxin contamination. Fortunately, with the advancement of society and the development of new materials, the human mycotoxicosis incidence has decreased gradually.

Fusarium toxin contamination in cereals remains an inevitable problem worldwide. In recent years, risk assessment and mycotoxin monitoring of cereals has been strengthened, and research in related fields has been promoted. However, achieving the goal of effectively controlling mycotoxin contamination in cereals is still a long way away. Integrated mycotoxin management practices, including preharvest control (e.g., tillage and crop rotation, selection of resistant varieties, proper sowing dates and density, irrigation and fertilization regimes, weed elimination, insect management, and chemical and biological control), harvest control (e.g., proper harvest time, professional mechanical equipment, mechanical damage reduction, effective cleaning, and impurity removal), and postharvest control (e.g., timely and efficient drying, good storage practices, and classified applications) should be employed to manage all possible risk factors to prevent mycotoxin contamination. In the future, with the effective implementation of good agricultural practices (GAPs), good manufacturing practices (GMPs), and hazard analysis critical control points (HACCPs), food safety, and consumer health can be improved and guaranteed as much as possible.

Table 6. Limits of DON and ZEN relate to cereals for food and feed in China.

\begin{tabular}{|c|c|c|c|}
\hline Food Category & Toxin & Limit $(\mu \mathrm{g} / \mathbf{k g})$ & Standard Code \\
\hline $\begin{array}{l}\text { cereal and its product: } \\
\text { corn, corn flour (corn gluten meal, corn flake), barley, } \\
\text { wheat, oatmeal, wheat flour }\end{array}$ & \multirow{6}{*}{$\mathrm{DON}$} & 1000 & GB2761 \\
\hline plant feedstuffs & & 5000 & \multirow{5}{*}{ GB13078 } \\
\hline calf, lamb, concentrate supplement in lactation period & & 1000 & \\
\hline other concentrate supplement & & 3000 & \\
\hline pig formula feed & & 1000 & \\
\hline other formula feed & & 3000 & \\
\hline $\begin{array}{l}\text { cereal and its product: wheat, wheat flour, corn, corn flour } \\
\text { (corn gluten meal, corn flake) }\end{array}$ & \multirow{9}{*}{ ZEN } & 60 & GB2761 \\
\hline $\begin{array}{c}\text { corn and its processed products } \\
\text { (corn bran, corn gluten feed, corn steep powder excepted) }\end{array}$ & & 500 & \multirow{8}{*}{ GB13078 } \\
\hline $\begin{array}{l}\text { corn bran, corn gluten feed, corn steep powder, } \\
\text { corn distiller's grains products }\end{array}$ & & 1500 & \\
\hline other plant feedstuffs & & 1000 & \\
\hline calf, lamb, concentrate supplement in lactation period & & 500 & \\
\hline piglet formula feed & & 150 & \\
\hline gilt formula feed & & 100 & \\
\hline other pig formula feed & & 250 & \\
\hline other formula feed & & 500 & \\
\hline
\end{tabular}


Table 7. Current detection standard for DON and ZEN by Chinese regulations.

\begin{tabular}{|c|c|c|c|c|}
\hline Standard Code & Standard Category & Standard Name & Method & Toxin \\
\hline GB 5009.111-2016 & $\begin{array}{c}\text { Mandatory } \\
\text { national standard }\end{array}$ & $\begin{array}{c}\text { Determination of deoxynivalenol and its } \\
\text { acetylated } \\
\text { derivatives in food }\end{array}$ & $\begin{array}{l}\text { Isotope-dilution LC-MS/MS; } \\
\text { Immunoaffinity } \\
\text { chromatography-HPLC; } \\
\text { thin layer chromatography }\end{array}$ & \multirow{10}{*}{ DON } \\
\hline GB/T 30956-2014 & \multirow{2}{*}{$\begin{array}{l}\text { Recommendatory national } \\
\text { standard }\end{array}$} & Determination of deoxynivalenol in feeds & $\begin{array}{l}\text { Immunoaffinity } \\
\text { chromatography-HPLC }\end{array}$ & \\
\hline GB/T 8381.6-2005 & & $\begin{array}{l}\text { Method for determination of } \\
\text { deoxynivalenol in formula feed }\end{array}$ & Thin layer chromatography & \\
\hline SN/T 3137-2012 & \multirow{2}{*}{$\begin{array}{l}\text { Recommendatory industry } \\
\text { standard }\end{array}$} & $\begin{array}{l}\text { Determination of deoxynivalenol, } \\
\text { 3-acety-ldeoxynivalenol, } \\
\text { 15-O-4-acetyl-deoxynivalenol, and their } \\
\text { metabolite in food for export }\end{array}$ & HPLC-MS/MS & \\
\hline SN/T 3136-2012 & & $\begin{array}{l}\text { Determination of aflatoxins, ochratoxin, } \\
\text { fumonisin B1, deoxynivalenol, T-2 and } \\
\text { HT-2 toxins in peanut, grains, and their } \\
\text { products for export }\end{array}$ & HPLC-MS/MS & \\
\hline LS/T 6110-2014 & $\begin{array}{l}\text { Recommendatory industry } \\
\text { standard }\end{array}$ & Detection of deoxynivalenol in cereal & $\begin{array}{l}\text { Rapid quantitative method of } \\
\text { colloidal gold technique }\end{array}$ & \\
\hline LS/T 6113-2015 & $\begin{array}{c}\text { Recommendatory industry } \\
\text { standard }\end{array}$ & Detection of deoxynivalenol in grain & $\begin{array}{l}\text { Rapid quantitative method of } \\
\text { colloidal gold technique }\end{array}$ & \\
\hline LS/T 6127-2017 & $\begin{array}{c}\text { Recommendatory industry } \\
\text { standard }\end{array}$ & Detection of deoxynivalenol in grain & UPLC & \\
\hline LS/T 6133-2018 & $\begin{array}{c}\text { Recommendatory industry } \\
\text { standard }\end{array}$ & Determination of 16 mycotoxins in cereal & HPLC-MS/MS & \\
\hline KJ 201702 & Rapid detection standard & $\begin{array}{l}\text { Rapid detection of deoxynivalenol in } \\
\text { food }\end{array}$ & $\begin{array}{c}\text { Colloidal gold } \\
\text { immunochromatographic }\end{array}$ & \\
\hline
\end{tabular}


Table 7. Cont

\begin{tabular}{|c|c|c|c|c|}
\hline Standard Code & Standard Category & Standard Name & Method & Toxin \\
\hline GB 5009.209-2016 & $\begin{array}{l}\text { Mandatory } \\
\text { national standard }\end{array}$ & Determination of zearalenone in food & $\begin{array}{c}\text { HPLC; HPLC-MS/MS; } \\
\text { Immunoaffinity } \\
\text { chromatography-fluorescence } \\
\text { spectrometer }\end{array}$ & \multirow{10}{*}{ ZEN } \\
\hline GB/T 19540-2004 & \multirow{2}{*}{$\begin{array}{l}\text { Recommendatory national } \\
\text { standard }\end{array}$} & Determination of zearalenone in feeds & $\begin{array}{c}\text { Thin layer chromatography; } \\
\text { Enzyme-linked immunosorbent assay }\end{array}$ & \\
\hline GB/T 28716-2012 & & Determination of zearalenone in feeds & $\begin{array}{l}\text { HPLC method with immunoaffinity } \\
\text { column clean-up }\end{array}$ & \\
\hline SN/T 3235-2012 & $\begin{array}{l}\text { Recommendatory industry } \\
\text { standard }\end{array}$ & $\begin{array}{l}\text { Determination of multi-groups of banned } \\
\text { drug residues in foodstuffs of Animal } \\
\text { origin for export }\end{array}$ & LC-MS/MS & \\
\hline SN/T 4058-2014 & $\begin{array}{l}\text { Recommendatory industry } \\
\text { standard }\end{array}$ & $\begin{array}{l}\text { Determination of residues of zeranols in } \\
\text { foodstuffs of animal origin for export }\end{array}$ & $\begin{array}{l}\text { HPLC and HPLC-MS/MS method } \\
\text { with Immunoaffinity column } \\
\text { clean-up }\end{array}$ & \\
\hline NY/T 2071-2011 & $\begin{array}{l}\text { Recommendatory agriculture } \\
\text { standard }\end{array}$ & $\begin{array}{l}\text { Determination of aflatoxins, zearalenone, } \\
\text { and T-2 in feed }\end{array}$ & LC-MS/MS & \\
\hline LS/T 6109-2014 & $\begin{array}{l}\text { Recommendatory agriculture } \\
\text { standard }\end{array}$ & Detection of zearalenone in cereal & $\begin{array}{l}\text { Rapid method of colloidal gold } \\
\text { technique }\end{array}$ & \\
\hline LS/T 6112-2015 & $\begin{array}{c}\text { Recommendatory agriculture } \\
\text { standard }\end{array}$ & Detection of zearalenone in grain & $\begin{array}{l}\text { Rapid quantitative method of } \\
\text { colloidal gold technique }\end{array}$ & \\
\hline LS/T 6129-2017 & $\begin{array}{c}\text { Recommendatory agriculture } \\
\text { standard }\end{array}$ & Determination of zearalenone in grains & UPLC-MS/MS & \\
\hline LS/T 6133-2018 & $\begin{array}{l}\text { Recommendatory industry } \\
\text { standard }\end{array}$ & Determination of 16 mycotoxins in cereal & HPLC-MS/MS & \\
\hline
\end{tabular}


Author Contributions: J.S. outlined the framework and J.Q. wrote the manuscript. J.X. and J.S. conceived this project. All authors read and approved the final manuscript.

Funding: This work was supported by National Natural Science Foundation of China $(31601594,31701748)$, Jiangsu Agriculture Science and Technology Innovation Fund (CX(17)1003), International Science \& Technology Cooperation Program of China (2016YFE0112900), National Key R\&D Program of China (2018YFD0200500).

Conflicts of Interest: The authors declare no conflict of interest.

\section{References}

1. Han, Y.J. Analysis on the development of China's wheat industry. Agric. Outlook 2006, 3, 3-7.

2. Cheng, S. Heavy metal pollution in China: Origin, pattern and control. Environ. Sci. Pollut. R. 2003, 10, 192-198. [CrossRef]

3. Hou, B.; Wang, Z.W.; Ying, R. Pesticide residues and wheat farmer's cognition: A China scenario. Agric. Res. 2016, 5, 51-63. [CrossRef]

4. Shi, J.R.; Liu, X.; Qiu, J.B.; Ji, F.; Xu, J.H.; Dong, F. Deoxynivalenol contamination in wheat and its management. Sci. Agric. Sin. 2016, 47, 3641-3654.

5. Shi, J.R.; Qiu, J.B.; Dong, F.; Xu, J.H.; Ji, F.; Liu, X.; Yu, M.Z. Risk of Fusarium toxins of wheat in China. J. Trit. Crops 2016, 36, 129-135.

6. Liu, A.; Shen, L.; Tan, Y.; Zeng, Z.; Liu, Y.; Li, C. Food integrity in china: Insights from the national food spot check data in 2016. Food Control 2018, 84, 403-407. [CrossRef]

7. Bottalico, A.; Perrone, G. Toxigenic Fusarium species and mycotoxins associated with head blight in small-grain cereals in Europe. Eur. J. Plant Pathol. 2002, 108, 1-26. [CrossRef]

8. Pestka, J.J. Deoxynivalenol: Mechanisms of action, human exposure, and toxicological relevance. Arch. Toxicol. 2010, 84, 663-679. [CrossRef]

9. Pestka, J.J.; Smolinski, A.T. Deoxynivalenol: Toxicology and potential effects on humans. J. Toxicol. Env. Heal. B 2005, 8, 39-69. [CrossRef]

10. Iverson, F.; Armstrong, C.; Nera, E.; Truelove, J.; Fernie, S.; Scott, P.; Stapley, R.; Hayward, S.; Gunner, S. Chronic feeding study of deoxynivalenol in b6c3f1 male and female mice. Teratog. Carcinog. Mutagen. 1995, 15, 283-306. [CrossRef] [PubMed]

11. Debouck, C.; Haubruge, E.; Bollaerts, P.; van Bignoot, D.; Brostaux, Y.; Werry, A.; Rooze, M. Skeletal deformities induced by the intraperitoneal administration of deoxynivalenol (vomitoxin) in mice. Int. Orthop. 2001, 25, 194-198. [CrossRef] [PubMed]

12. Bony, S.; Olivier-Loiseau, L.; Carcelen, M.; Devaux, A. Genotoxic potential associated with low levels of the Fusarium mycotoxins nivalenol and fusarenon $X$ in a human intestinal cell line. Toxicol. In Vitro 2007, 21, 457-465. [CrossRef]

13. Marin, D.E.; Pistol, G.C.; Neagoe, I.V.; Calin, L.; Taranu, I. Effects of zearalenone on oxidative stress and inflammation in weanling piglets. Food Chem. Toxicol. 2013, 58, 408-415. [CrossRef] [PubMed]

14. Gromadzka, K.; Waskiewicz, A.; Chelkowski, J.; Golinski, P. Zearalenone and its metabolites: Occurrence, detection, toxicity and guidelines. World Mycotoxin J. 2008, 1, 209-220. [CrossRef]

15. Luo, X.Y. Food poisoning caused by Fusarium toxins. In Proceedings of the Second Asian Conference on Food Safety, Chatuchak, Bangkok, Thailand; International Life Sciences Institute: Washington, DC, USA, 1994; pp. 129-136.

16. Tang, S.D.; Su, C.Y.; Guo, S.W. Investigation report of food poisoning caused by scabby wheat in Xintian, Lingtao. Prog. Food Hygi. 1988, 5, 69.

17. Luo, X.Y.; Li, Y.W.; Wen, S.F.; Hu, X. Determination of Fusarium mycotoxins in scabby wheat associated with human red-mold intoxication. J. Hygiene Res. 1987, 16, 33-37.

18. He, X.M.; Chen, Z.Q. Four outbreaks of human mycotoxicoses associated with the consumption of corn or wheat powder contaminated with deoxynivalenol. Guangxi Med. J. 1990, 12, 205-206.

19. Liu, J.R.; Tan, Q.Y.; Luo, X.Y. An outbreak of food poisoning caused by scab wheat. Chin. J. Food Hygi. 1989, $1,62-63$.

20. Xu, Z.Z.; Yang, T.Z.; Zeng, X.G. An outbreak of food poisoning caused by scab wheat. J. Nanjing Med. Univ. 1991, 11, 48-50. 
21. Luo, X.Y. Fusarium toxins contamination of cereals in China. Proc. Jpn. Assoc. Mycotoxicol. 1991, 33, 11-15. [CrossRef]

22. Guo, B.H.; Wei, T.; Wang, Z.Z.; Wang, H.; Dong, C.J.; Zhou, S.T.; Liu, X.N.; Li, Y.H.; He, X.Y.; Fang, C.H. Epidemiological investigation report on diarrhea and other main disease in xincai county, Henan Province after flood. Henan J. Prev. Med. 1991, 2, 882-886.

23. Yang, C.H.; Luo, X.Y.; Li, W.Y.; Liu, C.; Li, Y.P. Survey on pollution of mycotoxin in moldy grains. J. Hygiene Res. 1992, 21, 258-260.

24. Yuan, B.J.; Cao, Y.J.; Chen, L.Q.; Gao, Z.S.; Kuang, Y.H. A survey of food poisoning of scab wheat in Xuyi county during disaster period. Chin. J. Food Hygi. 1993, 5, 44-46.

25. Chen, Y.Q.; Cheng, F.J.; Cai, J.L.; Yao, Z.F. Investigation on a food poisoning caused by eating scabby wheat. Strait J. Prev. Med. 1998, 4, 31-32.

26. Sun, L.J.; Tain, X.C.; Yao, S.S. An outbreak of food poisoning caused by scab wheat flour. Heilongjiang Med. J. 2001, 25, 304.

27. Chen, G.S.; Wu, K.H.; Chang, J.L. An outbreak of food poisoning caused by scab wheat. Henan J. Prev. Med. 2003, 14, 366 .

28. Shi, H.G.; Zhou, H.Y. Investigation on the poisoning cause of eating scabby wheat. Mod. Prev. Med. 2005, 32, 1165.

29. Li, F.Q.; Li, Y.W.; Luo, X.Y.; Yoshizawa, T. Fusarium toxins in wheat from an area in Henan Province, PR China, with a previous human red mould intoxication episode. Food Addit. Contam. 2002, 19, 163-167. [CrossRef]

30. Lv, S.Q.; Wang, L.J.; Wang, Z.L. T-2 Toxin and Kashin-Beck disease. Chin. J. Control Endem. Dis. 2000, 15, 35-39.

31. Luo, Y.; Zheng, J.S.; Yang, J.S.; Liu, F.; Yoshizawa, T.; Zhang, S.Y.; Zhang, B.J.; Liu, K.C.; Zhai, S.S.; Sha, R.; et al. Determination of Fusarium mycotoxins in corn and wheat from Kaschin-Beck disease areas. Chin. J. Control Endem. Dis. 1992, 7, 71-75.

32. Lei, R.; Jiang, N.; Zhang, Q.; Hu, S.; Dennis, B.S.; He, S.; Guo, X. Prevalence of selenium, T-2 toxin, and deoxynivalenol in kashin-beck disease areas in Qinghai Province, northwest China. Biol. Trace Elem. Res. 2016, 171, 34-40. [CrossRef]

33. Hou, H.F.; Chen, L.M.; Han, J.J.; Li, J.P.; Ding, G.Y.; Qiu, J.; Li, Q.W. Report of deoxynivalenol and selenium in high incidence areas with kaschin-beck disease. Chin. J. Prev. Med. 2010, 44, 663-664.

34. Liu, H.; Zhou, L.W.; Liu, Y.Q. Analysis of national surveillance on kashin-beck disease condition from 2000 to 2007. Chin. J. Control Endem. Dis. 2009, 28, 554-558.

35. Luo, Y.; Yoshizawa, T.; Katayama, T. Comparative study on the natural occurrence of Fusarium mycotoxins (trichothecenes and zearalenone) in corn and wheat from high-and low-risk areas for human esophageal cancer in China. Appl. Environ. Microb. 1990, 56, 3723-3726.

36. Gao, H.P.; Yoshizawa, T. Further study on Fusarium mycotoxins in corn and wheat from a high-risk area for human esophageal cancer in China. Mycotoxins 1997, 45, 51-55. [CrossRef]

37. Yoshizawa, T.; Gao, H.P. Risk assessment of mycotoxins in staple foods from the high-risk area for human esophageal cancer in China. Mycotoxins 1999, (Suppl. 2), 55-62. [CrossRef]

38. Hou, H.F.; Chen, L.M.; Qiu, J.; Li, J.P.; Dong, F.; Li, Q.W. Determination of deoxynivalenol and selenium in high incidence areas with esophageal cancer in Shandong. China Cancer 2011, 20, 406-408.

39. Hsia, C.C.; Wu, Z.Y.; Li, Y.S.; Zhang, F.; Sun, Z.T. Nivalenol, a main Fusarium toxin in dietary foods from high-risk areas of cancer of esophagus and gastric cardia in China, induced benign and malignant tumors in mice. Oncol. Rep. 2004, 12, 449-456. [CrossRef]

40. Sydenham, E.W.; Thiel, P.G.; Marasas, W.F.; Shephard, G.S.; van Schalkwyk, D.J.; Koch, K.R. Natural occurrence of some Fusarium mycotoxins in corn from low and high esophageal cancer prevalence areas of the Transkei, Southern Africa. J. Agr. Food Chem. 1990, 38, 1900-1903. [CrossRef]

41. Xu, Y.G.; Chen, L.F. Wheat Scab: Theory and Practice on Control; Jiangsu Sci. Tech. Publ. House: Nanjing, China, 1993; pp. 201-216.

42. Miller, J.D.; Greenhalgh, R.; Wang, Y.Z.; Lu, M. Trichothecene mycotoxin chemotypes of three Fusarium species. Mycologia 1991, 83, 121-130. [CrossRef]

43. Wang, Y.Z.; Miller, J.D. Toxin producing potential of Fusarium graminearum from China. Acta Mycologica Sinica 1994, 13, 229-234. 
44. All China Corporation of Research on Wheat Scab. Fusarium species distribution and pathogenicity from scabby heads in China. J. Shanghai Normal Univ. (Nat. Sci.) 1984, 3, 69-82.

45. Zhang, R.T.; Huang, L.H.; Lei, G.X.; Dong, C.S.; Liu, C.F. Preliminary study on identification of pathogen causing wheat head blight in Qinghai Province. J. Hunan Agric. Univ. (Nat. Sci.) 1983, 2, 71-78.

46. Zheng, Y.M.; Lin, Z.F.; Zhu, Z.D. Study of pathogen species and forms wheat scab fungi in Fujian Province. Acta Phytopathol. Sin. 1983, 13, 53-59.

47. Hu, G.L.; Zhou, L.H. Identification of pathogen causing wheat head blight in Henan Province. J. Henan Univ. Sci. Technol. (Agric. Sci.) 1992, 4, 395-399.

48. Xie, Y.S.; Mu, Y.S.; Qiu, Y. Identification and pathogenicity of pathogen causing wheat head blight in Ningxia. J. Agric.Sci. 1989, 10, 33-38.

49. Sarver, B.A.; Ward, T.J.; Gale, L.R.; Broz, K.; Kistler, H.C.; Aoki, T.; Nicholson, P.; Carter, J.; O’Donnell, K. Novel Fusarium head blight pathogens from Nepal and Louisiana revealed by multilocus genealogical concordance. Fungal Genet. Biol. 2011, 48, 1096-1107. [CrossRef] [PubMed]

50. O'Donnell, K.; Ward, T.J.; Aberra, D.; Kistler, H.C.; Aoki, T.; Orwig, N.; Kimura, M.; Bjornstad, S.; Klemsdal, S.S. Multilocus genotyping and molecular phylogenetics resolve a novel head blight pathogen within the Fusarium graminearum species complex from Ethiopia. Fungal Genet. Biol. 2008, 45, 1514-1522. [CrossRef] [PubMed]

51. Suga, H.; Karugia, G.W.; Ward, T.; Gale, L.R.; Tomimura, K.; Nakajima, T.; Miyasaka, A.; Koizumi, S.; Kageyama, K.; Hyakumachi, M. Molecular characterization of the Fusarium graminearum species complex in Japan. Phytopathology 2008, 98, 159-166. [CrossRef]

52. Lee, J.; Kim, H.; Jeon, J.J.; Kim, H.S.; Zeller, K.A.; Carter, L.L.; Leslie, J.F.; Lee, Y.W. Population structure of and mycotoxin production by Fusarium graminearum from maize in South Korea. Appl. Environ. Microbiol. 2012, 78, 2161-2167. [CrossRef]

53. Desjardins, A.E. Fusarium. Mycotoxins: Chemistry, Genetics, and Biology; APS Press: St. Paul, MN, USA, 2006.

54. Ward, T.J.; Bielawski, J.P.; Kistler, H.C.; Sullivan, E.; O’Donnell, K. Ancestral polymorphism and adaptive evolution in the trichothecene mycotoxin gene cluster of phytopathogenic Fusarium. Proc. Natl. Acad. Sci. USA 2002, 99, 9278-9283. [CrossRef] [PubMed]

55. Zhang, J.B.; Li, H.P.; Dang, F.J.; Qu, B.; Liao, Y.C. Determination of the trichothecene mycotoxin chemotypes and associated geographical distribution and phylogenetic species of the Fusarium graminearum clade from china. Mycol. Res. 2007, 111, 967-975. [CrossRef] [PubMed]

56. Karugia, G.W.; Suga, H.; Gale, L.R.; Nakajima, T.; Ueda, A.; Hyakumachi, M. Population structure of Fusarium asiaticum from two Japanese regions and eastern China. J. Gen. Plant Pathol. 2009, 75, 110-118. [CrossRef]

57. Puri, K.D.; Saucedo, E.S.; Zhong, S. Molecular characterization of Fusarium head blight pathogens sampled from a naturally infected disease nursery used for wheat breeding programs in China. Plant Dis. 2012, 96, 1280-1285. [CrossRef]

58. Pan, X.J.; Chen, N.; Yao, Y.; Liu, X.; Gao, Z.G. Population and pathogenicity of Fusarium spp. causing wheat head blight in northeast of China. Acta Agric. Boreali-Sin. 2015, 30, 205-210.

59. Liu, X.X.; Wang, Y.; Qiu, J.F.; Meng, F.L.; Wei, C.Y. Analysis of toxin contamination in spring wheat, species and mycotoxin chemotypes of Fusarium spp. in northern China. Jiangsu Agric. Sci. 2018, 46, 199-202.

60. Qiu, J.; Xu, J.; Shi, J. Molecular characterization of the Fusarium graminearum species complex in Eastern China. Eur. J. Plant Pathol. 2014, 139, 811-823. [CrossRef]

61. Qiu, J.B.; Sun, J.T.; Yu, M.Z.; Xu, J.H.; Shi, J.R. Temporal dynamics, population characterization and mycotoxins accumulation of Fusarium graminearum in Eastern China. Sci. Rep.-UK 2016, 6, 36350. [CrossRef]

62. Ward, T.J.; Clear, R.M.; Rooney, A.P.; O’Donnell, K.; Gaba, D.; Patrick, S.; Starkey, D.E.; Gilbert, J.; Geiser, D.M.; Nowicki, T.W. An adaptive evolutionary shift in Fusarium head blight pathogen populations is driving the rapid spread of more toxigenic Fusarium graminearum in North America. Fungal Genet. Biol. 2008, 45, 473-484. [CrossRef]

63. Puri, K.D.; Zhong, S. The 3ADON population of Fusarium graminearum found in North Dakota is more aggressive and produces a higher level of DON than the prevalent 15ADON population in spring wheat. Phytopathology 2010, 100, 1007-1014. [CrossRef]

64. Kelly, A.C.; Clear, R.M.; O’Donnell, K.; McCormick, S.; Turkington, T.K.; Tekauz, A.; Gilbert, J.; Kistler, H.C.; Busman, M.; Ward, T.J. Diversity of Fusarium head blight populations and trichothecene toxin types reveals regional differences in pathogen composition and temporal dynamics. Fungal Genet. Biol. 2015, 82, $22-31$. [CrossRef] 
65. Liang, J.M.; Xayamongkhon, H.; Broz, K.; Dong, Y.; McCormick, S.P.; Abramova, S.; Ward, T.J.; Ma, Z.H.; Kistler, H.C. Temporal dynamics and population genetic structure of Fusarium graminearum in the upper Midwestern United States. Fungal Genet. Biol. 2014, 73, 83-92. [CrossRef] [PubMed]

66. Zhang, H.; Zhang, Z.; Van der Lee, T.; Chen, W.Q.; Xu, J.; Xu, J.S.; Yang, L.; Yu, D.; Waalwijk, C.; Feng, J. Population genetic analyses of Fusarium asiaticum populations from barley suggest a recent shift favoring 3ADON producers in southern China. Phytopathology 2010, 100, 328-336. [CrossRef]

67. Yang, M.; Zhang, H.; Kong, X.; van der Lee, T.; Waalwijk, C.; van Diepeningen, A.; Xu, J.; Chen, W.Q.; Feng, J. Host and cropping system shape the Fusarium population: 3ADON-producers are ubiquitous in wheat whereas NIV-producers are more prevalent in rice. Toxins 2018, 10, 115. [CrossRef] [PubMed]

68. Chen, L.F.; Zhao, Y.J. Identification of pathogen causing wheat head blight in Qinghai Province. J. Nanjing Agric. Univ. 1996, 19, 116-118.

69. Zhao, Y.J. Identification and pathogenicity of pathogen causing wheat head blight in Haidong district in Qinghai Province. Plant Protection 2001, 27, 1-19.

70. Xu, F.; Yang, G.Q.; Wang, J.M.; Song, J.L.; Liu, L.L.; Zhang, J.J. Composition and variation in aggressiveness of populations causing wheat head blight in Henan Province. Acta Phytopathol. Sin. 2016, 46, 294-303.

71. Zhang, H.; van der Lee, T.; Waalwijk, C.; Chen, W.; Xu, J.; Xu, J.; Zhang, Y.; Feng, J. Population analysis of the Fusarium graminearum species complex from wheat in china show a shift to more aggressive isolates. PLoS ONE 2012, 2, e31722.

72. Shi, W.Q.; Yang, L.J.; Feng, J.; Zhang, X.; Zeng, F.S.; Xiang, L.B.; Wang, H.; Yu, D.Z. Analysis on the population structure of Fusarium pathogenic spp. and its mycotoxin chemotypes in Fusarium head blight epidemic region. Acta Phytopathol. Sin. 2011, 41, 486-494.

73. Shen, C.M.; Hu, Y.C.; Sun, H.Y.; Li, W.; Guo, J.H.; Chen, H.G. Geographic distribution of trichothecene chemotypes of the Fusarium graminearum species complex in major winter wheat production areas of China. Plant Dis. 2012, 96, 1172-1178. [CrossRef]

74. Zhang, J.B.; Wang, J.H.; Gong, A.D.; Chen, F.F.; Song, B.; Li, X.; Li, H.P.; Peng, C.H.; Liao, Y.C. Natural occurrence of Fusarium head blight, mycotoxins and mycotoxin-producing isolates of Fusarium in commercial fields of wheat in Hubei. Plant Pathol. 2013, 62, 92-102. [CrossRef]

75. Zhang, H.B.; Liu, J.W.; Liu, B.J.; Liu, B.; Liang, Y.C. Composition and pathogenicity differentiation of pathogenic species isolated from Fusarium head blight in Shandong Province. J. Plant Protec. 2013, 40, $27-32$.

76. Gao, X.Y.; Gao, S.M.; liu, S.J.; Zhang, L.; Yu, J.F. Analysis on the species composition and mycotoxin chemotypes of wheat Fusarium head blight in Shandong Province. Acta Agric. Boreali-Sin. 2017, 32, 37-42.

77. Wei, N.; Zhang, F.L.; Zhang, Y.F. Distribution of fungal toxin contamination in main grain and oil crops on the Tibetan plateau. Quality Safety Agr.-Prod. 2018, 3, 68-72.

78. $\mathrm{Si}$, L.L. Analysis of the monitoring results of deoxynivalenol and zearalenone in wheat flour and cornmeal in Lasa. Tibet Sci. Tech. 2014, 12, 25-28.

79. Yang, X.L.; Zhang, G.X.; Yang, Q.D. Contamination survey of the deoxynivalenols in wheat flour from in the market of Xinjiang. Chin. J. Health Lab. Tec. 2016, 4, 578-581.

80. Guo, H.W.; Liu, Q.P.; Hu, Z.H.; Xu, D.D.; Tanaka, T.; Ueno, Y.; Wu, Q.F. The contamination of Fusarium toxins in wheat and the intake of these toxins by farmers. Chin. J. Food Hygi. 1989, 1, 20-24.

81. Lu, G.; Xue, Y.; Li, L. Contamination surveys of deoxynivalenol in wheat, flour, corn and barley from severe epidemic regions of scab in Anhui Province. Chin. J. Food Hygi. 1992, 3, 66.

82. Cao, Y.J.; Cai, M.; Zhou, S.N.; Yan, X.P. Contamination surveys of the deoxynivalenol of corn and flour in Jiangsu Province. Chin. J. Food Hygi. 1994, 4, 36-37.

83. Lu, G.; Li, L. Studies on deoxynivalenol contamination in grain and its products in Anhui Province. Chin. J. Prev. Med. 1994, 1, 27-30.

84. Cui, L.; Selvaraj, J.N.; Xing, F.; Zhao, Y.; Zhou, L.; Liu, Y. A minor survey of deoxynivalenol in Fusarium infected wheat from Yangtze-Huaihe river basin region in China. Food Control 2013, 30, 469-473. [CrossRef]

85. Selvaraj, J.N.; Zhao, Y.; Sangare, L.; Xing, F.; Zhou, L.; Wang, Y.; Xue, X.; Li, Y.; Liu, Y. Limited survey of deoxynivalenol in wheat from different crop rotation fields in Yangtze-Huaihe river basin region of China. Food Control 2015, 53, 151-155. [CrossRef]

86. Xu, W.; Han, X.; Li, F. Co-occurrence of multi-mycotoxins in wheat grains harvested in Anhui Province, China. Food Control 2019, 96, 180-185. [CrossRef] 
87. Ji, F.; Xu, J.; Liu, X.; Yin, X.; Shi, J. Natural occurrence of deoxynivalenol and zearalenone in wheat from Jiangsu Province, China. Food Chem. 2014, 157, 393-397. [CrossRef]

88. Ji, F.; Mokoena, M.P.; Zhao, H.; Olaniran, A.O.; Shi, J. Development of an immunochromatographic strip test for the rapid detection of zearalenone in wheat from Jiangsu Province, China. PLoS ONE 2017, 12, e0175282. [CrossRef]

89. Dong, F.; Wang, S.; Yu, M.; Sun, Y.; Xu, J.; Shi, J. Natural occurrence of deoxynivalenol and deoxynivalenol-3-glucoside in various wheat cultivars grown in Jiangsu Province, China. World Mycotoxin J. 2017, 10, 285-293. [CrossRef]

90. Berthiller, F.; Dall'Asta, C.; Schuhmacher, R.; Lemmens, M.; Adam, G.; Krska, R. Masked mycotoxins: Determination of a deoxynivalenol glucoside in artificially and naturally contaminated wheat by liquid chromatography-tandem mass spectrometry. J. Agr. Food Chem. 2005, 53, 3421-3425. [CrossRef]

91. Poppenberger, B.; Berthiller, F.; Lucyshyn, D.; Sieberer, T.; Schuhmacher, R.; Krska, R.; Kuchler, K.; Glössl, J.; Luschnig, C.; Adam, G. Detoxification of the Fusarium mycotoxin deoxynivalenol by a UDP-glucosyltransferase from Arabidopsis thaliana. J. Biol. Chem. 2003, 278, 47905-47914. [CrossRef]

92. Berthiller, F.; Dall'Asta, C.; Corradini, R.; Marchelli, R.; Sulyok, M.; Krska, R.; Adam, G.; Schuhmacher, R. Occurrence of deoxynivalenol and its 3- $\beta$-D-glucoside in wheat and maize. Food Addit. Contam. 2009, 4, 507-511. [CrossRef]

93. Berthiller, F.; Krska, R.; Domig, K.J.; Kneifel, W.; Juge, N.; Schuhmacher, R.; Adam, G. Hydrolytic fate of deoxynivalenol-3-glucoside during digestion. Toxicol. Lett. 2011, 3, 264-267. [CrossRef]

94. Sasanya, J.J.; Hall, C.; Wolf-Hall, C. Analysis of deoxynivalenol, masked deoxynivalenol, and Fusarium graminearum pigment in wheat samples, using liquid chromatography-UV-mass spectrometry. J. Food Protect. 2008, 6, 1205-1213. [CrossRef]

95. Li, F.Q.; Yu, C.C.; Shao, B.; Wang, W.; Yu, H.X. Natural occurrence of masked deoxynivalenol and multi-mycotoxins in cereals from china harvested in 2007 and 2008. Chin. J. Prev. Med. 2011, 45, 57-63.

96. Ma, J.J.; Shao, B.; Lin, X.H.; Yu, H.X.; Li, F.Q. Study on the natural occurrence of multi-mycotoxin in cereal and cereal-based product samples collected from parts of China in 2010. Chin. J. Food Hygi. 2011, 23, 481-488.

97. Han, X.M.; Li, F.Q.; Xu, W.J.; Zhang, H.Y.; Zhang, J.; Zhao, X.; Xu, J.; Han, C.H. Natural occurrence of important mycotoxins produced by Fusarium in wheat flour from five Provinces in China. China Swine Ind. 2017, 12, 33-39.

98. Li, F.; Jiang, D.; Zhou, J.; Chen, J.; Li, W.; Zheng, F. Mycotoxins in wheat flour and intake assessment in Shandong Province of China. Food Addit. Contam. B 2016, 9, 170-175. [CrossRef]

99. Gong, L.; Han, Z.; Cheng, H.; Liu, J.; Peng, Q.Z. The determination and the analysis of contamination law of deoxynivalenol and derivatives in cereals and their products. Food Sci. 2019. Available online: http://kns.cnki.net/kcms/detail/11.2206.TS.20181214.1620.108.html (accessed on 31 March 2019).

100. Liu, Y.; Lu, Y.; Wang, L.; Chang, F.; Yang, L. Survey of 11 mycotoxins in wheat flour in Hebei Province, China. Food Addit. Contam. B 2015, 4, 250-254. [CrossRef]

101. Jin, M.T.; Wang, J.H.; Lin, S.H.; Sun, W.S.; Wu, A.B. Analysis of deoxynivalenol (DON) and masked deoxynivalenol (D3G) accumulation in different treatment wheat grains at room temperature. Sci. Tech. Food Ind. 2015, 17, 132-137.

102. Luo, X.Y. Contamination of Fusarium toxin in cereals. Chin. J. Food Hygi. 1989, 1, 42-45.

103. Liao, X.G.; Zhang, X.L.; Chen, Y.R.; Gao, J.Q.; Wang, Z.Z.; Li, Y.W.; Wei, R.Y.; Li, Y.P. Detection of molds and mycotoxins in new wheat from flood areas in Henan Province in 1991. Chin. J. Health Lab. Tec. 1992, 4, 211-213.

104. Li, X.; Guo, H.W. Surveillance on contamination of Fusarium toxin in cereals from Shanghai. Chin. J. Publ. Heal. 1998, 14, 734 .

105. Han, Z.; Nie, D.; Ediage, E.N.; Yang, X.; Wang, J.; Chen, B.; Li, S.; On, S.L.; De Saeger, S.; Wu, A. Cumulative health risk assessment of co-occurring mycotoxins of deoxynivalenol and its acetyl derivatives in wheat and maize: Case study, Shanghai, China. Food Chem. Toxicol. 2014, 74, 334-342. [CrossRef]

106. Zhao, Y.; Guan, X.; Zong, Y.; Hua, X.; Xing, F.; Wang, Y.; Wang, F.; Liu, Y. Deoxynivalenol in wheat from the Northwestern region in China. Food Addit. Contam. B 2018, 11, 281-285. [CrossRef]

107. Ueno, Y.; Lee, U.S.; Tanaka, T.; Hasegawa, A.; Matsuki, Y. Examination of Chinese and U.U.U.R. cereals for the Fusarium mycotoxins, nivalenol, deoxynivalenol and zearalenone. Toxicon 1986, 24, 618-621. [CrossRef] 
108. Li, R.T.; Xie, G.; Fu, P.C.; Luo, J.; Chen, L.; Wu, J. A preliminary survey and analysis of zearalenone contamination in stored wheat and maize in china (I). Grain Storage 2004, 5, 36-38.

109. Wang, X.Y.; Yu, Y.Q.; Yu, Q. Contamination surveys and exposure assessment of the deoxynivalenol in resident meals in china in 2005. J. Changzhi Med. Coll. 2007, 21, 101-103.

110. Wu, J.; Liu, T.G.; Gao, L.; Zhu, B.C.; Chen, W.Q. Determination of four Fusarium mycotoxins using enzyme-linked immunosorbent assay and its contamination analysis in wheat. J. Plant Protec. 2009, 36, 106-112.

111. Xiong, K.H.; Hu, W.; Wang, M.J.; Wei, H.; Cheng, C.B. A survey on contamination of deoxynivalenol and zearalenone in maize and wheat from Anhui and Henan Province. Food Sci. 2009, 30, 265-268.

112. Sun, J.; Wu, Y. Evaluation of dietary exposure to deoxynivalenol (DON) and its derivatives from cereals in China. Food Control 2016, 69, 90-99. [CrossRef]

113. Liu, G.H.; Hou, G.L.; Guo, Z.H.; Wang, W.R.; Zhang, R.A.; Hou, F.L. Contamination surveys of the deoxynivalenol of corn and flour in Hebei Province. Chin. J. Food Hygi. 1993, 1, 40-41.

114. Lu, G.; Li, L.; Xue, Y. Contamination surveys of the deoxynivalenol of corn and flour in Anhui Province. Chin. J. Food Hygi. 1994, 1, 53-54.

115. Guo, H.W.; Zhu, Y.Z.; Liu, Q.P. Contamination surveys of the deoxynivalenol of corn and flour in Shanghai. Chin. J. Food Hygi. 1995, 5, 39-40.

116. Wang, W.; Shao, B.; Zhu, J.; Yu, H.; Li, F. Dietary exposure assessment of some important Fusarium toxins in cereal-based products in China. J. Hygiene Res. 2010, 39, 709-714.

117. Lu, J.J.; Yang, D.J. Pollution investigation of deoxynivalenol in wheat flour of China in 2013. J. Hygiene Res. 2015, 44, 658-660.

118. Liu, Y.; Lu, Y.; Wang, L.; Chang, F.; Yang, L. Occurrence of deoxynivalenol in wheat, Hebei Province, China. Food Chem. 2016, 197, 1271-1274. [CrossRef]

119. Wang, S.; Zhang, H.; Cui, Y.; Chen, W.S. The Investigation of DON contents in wheat powder samples and analysis of DON dietary exposure risk. Food Res. Dev. 2014, 22, 94-96.

120. Bai, Y.Y.; Chen, L.H.; Jia, Y.Z. Analysis of the monitoring results of three categories of mycotoxins in wheat flour and cornmeal from Xiamen markets in 2013. Chin. J. Health Lab. Tec. 2014, 14, 2068-2069.

121. Zhu, H.Y.; Luo, X.Y.; Lin, Y.N. Investigation on DON contamination of flour and flour-related food in Guangzhou. Jiangsu J. Prev. Med. 2013, 24, 14-15.

122. Hu, J.W.; Qiao, H.O.; Tian, L.; Wang, M.J.; Wang, C.X.; Guo, R. Mycotoxin contamination in cereal and its product in Shannxi Province from 2013 to 2016. J. Hygiene Res. 2017, 6, 158-160.

123. He, H.H.; Li, L.; Han, X.X.; Zheng, X.L.; Bian, K. Study on microorganism and mycotoxins contamination situation of commercial wheat flour in Henan Province. Cereals $\mathcal{E}$ Oils 2015, 12, 64-66.

124. Wang, L.Y.; Ren, B.B.; Yang, L.X.; Lu, Y.; Chang, F.Q.; Liu, Y.P. Investigation and analysis of deoxynivalenol and its derivatives pollution levels in cereal and cereal-based product in Hebei. Chin. J. Food Hygi. 2015, 27, 571-575.

125. Li, S.; Yuan, P.; Fu, P.Y.; Yang, L.; Zhang, S.F. Investigation of contamination situation of fungal toxin in some food in Henan Province from 2014 to 2015. Chin. Heal. Ind. 2017, 27, 144-147.

126. Zhang, Y.; Pei, F.; Fang, Y.; Li, P.; Zhao, Y.; Shen, F.; Zou, Y.; Hu, Q. Comparison of concentration and health risks of 9 Fusarium mycotoxins in commercial whole wheat flour and refined wheat flour by multi-IAC-HPLC. Food Chem. 2019, 275, 763-769. [CrossRef]

127. Ji, X.; Yang, H.; Wang, J.; Li, R.; Zhao, H.; Xu, J.; Xiao, P.; tang, B.; Qian, M. Occurrence of deoxynivalenol $(\mathrm{DON})$ in cereal-based food products marketed through e-commerce stores and an assessment of dietary exposure of Chinese consumers to DON. Food Control 2018, 92, 391-398. [CrossRef]

128. Wong, P.; Walter, M.; Lee, W.; Mannhaupt, G.; Munsterkotter, M.; Mewes, H.W.; Adam, G.; Guldener, U. FGDB: Revisiting the genome annotation of the plant pathogen Fusarium graminearum. Nucleic Acids Res. 2011, 39, D637-D639. [CrossRef]

129. Kimura, M.; Tokai, T.; Takahashi-Ando, N.; Ohsato, S.; Fujimura, M. Molecular and genetic studies of Fusarium trichothecene biosynthesis: Pathways, genes and evolution. Biosci. Biotechnol. Biochem. 2007, 71, 2105-2123. [CrossRef]

130. Seong, K.Y.; Pasquali, M.; Zhou, X.; Song, J.; Hilbrun, K.; McCormick, S.P.; Dong, Y.; Xu, J.R.; Kistler, H.C. Global gene regulation by Fusarium transcription factors Tri6 and Tri10 reveals adaptations for toxin biosynthesis. Mol. Microbiol. 2009, 72, 354-367. [CrossRef] 
131. Kim, Y.T.; Lee, Y.R.; Jin, J.; Han, K.H.; Kim, H.; Kim, J.C.; Lee, T.; Yun, S.H.; Lee, Y.W. Two different polyketide synthase genes are required for synthesis of zearalenone in Gibberella zeae. Mol. Microbiol. 2005, 58, 1102-1113. [CrossRef]

132. Lysøe, E.; Bone, K.R.; Klemsdal, S.S. Real-time quantitative expression studies of the zearalenone biosynthetic gene cluster in Fusarium graminearum. Phytopathology 2009, 99, 176-184. [CrossRef]

133. Gardiner, D.M.; Osborne, S.; Kazan, K.; Manners, J.M. Low pH regulates the production of deoxynivalenol by Fusarium graminearum. Microbiology 2009, 155, 3149-3156. [CrossRef] [PubMed]

134. Merhej, J.; Boutigny, A.L.; Pinson-Gadais, L.; Richard-Forget, F.; Barreau, C. Acidic pH as a determinant of TRI gene expression and trichothecene B biosynthesis in Fusarium graminearum. Food Addit. Contam. A 2010, 27, 710-717. [CrossRef] [PubMed]

135. Jiao, F.; Kawakami, A.; Nakajima, T. Effects of different carbon sources on trichothecene production and Tri gene expression by Fusarium graminearum in liquid culture. FEMS Microbiol. Lett. 2008, 285, 212-219. [CrossRef] [PubMed]

136. Gardiner, D.M.; Kazan, K.; Manners, J.M. Nutrient profiling reveals potent inducers of trichothecene biosynthesis in Fusarium graminearum. Fungal Genet. Biol. 2009, 46, 604-613. [CrossRef] [PubMed]

137. Hou, R.; Jiang, C.; Zheng, Q.; Wang, C.; Xu, J.R. The AreA transcription factor mediates the regulation of deoxynivalenol (DON) synthesis by ammonium and cyclic adenosine monophosphate (cAMP) signalling in Fusarium graminearum. Mol. Plant Pathol. 2015, 16, 987-999. [CrossRef]

138. Ponts, N.; Pinson-Gadais, L.; Barreau, C.; Richard-Forget, F.; Ouellet, T. Exogenous $\mathrm{H}_{2} \mathrm{O}_{2}$ and catalase treatments interfere with Tri genes expression in liquid cultures of Fusarium graminearum. FEBS Lett. 2007, 581, 443-447. [CrossRef] [PubMed]

139. Kokkonen, M.; Ojala, L.; Parikka, P.; Jestoi, M. Mycotoxin production of selected Fusarium species at different culture conditions. Int. J. Food Microbiol. 2010, 143, 17-25. [CrossRef]

140. Hou, Z.; Xue, C.; Peng, Y.; Katan, T.; Kistler, H.C.; Xu, J.R. A mitogen-activated protein kinase gene (MGV1) in Fusarium graminearum is required for female fertility, heterokaryon formation, and plant infection. Mol. Plant Microbe In. 2002, 15, 1119-1127. [CrossRef]

141. Guo, L.; Breakspear, A.; Zhao, G.; Gao, L.; Kistler, H.C.; Xu, J.R.; Ma, L.J. Conservation and divergence of the cyclic adenosine monophosphate-protein kinase A (cAMP-PKA) pathway in two plant-pathogenic fungi: Fusarium graminearum and F. verticillioides. Mol. Plant Pathol. 2016, 17, 196-209. [CrossRef] [PubMed]

142. Hu, S.; Zhou, X.; Gu, X.; Cao, S.; Wang, C.; Xu, J.R. The cAMP-PKA pathway regulates growth, sexual and asexual differentiation, and pathogenesis in Fusarium graminearum. Mol. Plant Microbe In. 2014, 27, 557-566. [CrossRef]

143. Yu, F.; Gu, Q.; Yun, Y.; Yin, Y.; Xu, J.R.; Shim, W.B.; Ma, Z. The TOR signaling pathway regulates vegetative development and virulence in Fusarium graminearum. New Phytol. 2014, 203, 219-232. [CrossRef]

144. Liu, Y.Y.; Sun, H.Y.; Li, W.; Xia, Y.L.; Deng, Y.Y.; Zhang, A.X.; Chen, H.G. Fitness of three chemotypes of Fusarium graminearum species complex in major winter wheat-producing areas of China. PLoS ONE 2017, 12, e0174040. [CrossRef] [PubMed]

145. Zhang, Y.J.; Yu, J.J.; Zhang, Y.N.; Zhang, X.; Cheng, C.J.; Wang, J.X.; Hollomon, D.W.; Fan, P.S.; Zhou, M.G. Effect of carbendazim resistance on trichothecene production and aggressiveness of Fusarium graminearum. Mol. Plant Microbe In. 2009, 22, 1143-1150. [CrossRef] [PubMed]

146. Li, H.K.; Zhou, M.G.; Wang, J.X.; NI, Y.P.; DIAO, Y.M. Controlling wheat scab with JS399-19 and carbendazim resistance management. Agrochemicals 2006, 45, 92-94.

147. Xu, F.; Wang, J.M.; Yang, G.Q.; Song, Y.L.; Zhao, K.; Han, Z.H.; Li, L.J.; Liu, L.L.; Li, Y.H.; Zhang, J.J. Effect of fungicide on Fusarium head blight and deoxynivalenol content in wheat grain. Plant Protection 2018, 44, 214-219.

148. Sun, H.Y.; Zhu, Y.F.; Liu, Y.Y.; Deng, Y.Y.; Li, W.; Zhang, A.X.; Chen, H.G. Evaluation of tebuconazole for the management of Fusarium head blight in China. Australas. Plant Path. 2014, 43, 631-638. [CrossRef]

149. Xu, F.; Song, Y.L.; Yang, G.Q.; Wang, J.M.; Zhao, K.; Han, Z.H.; Li, L.J.; Liu, L.L.; Li, Y.H.; Zhang, J.J. Effect of tebuconazole application time on Fusarium head blight and the accumulation of deoxynivalenol in winter wheat. Plant Protection 2018, 44, 179-185.

150. Han, Q.M.; Kang, Z.S.; Duan, S.K.; Huang, L.L. Chemical control of Fusarium head blight on wheat. J. Northwest Sci.-Tech. Univ. Agri. For. (Nat. Sci.) 2005, 33, 11-15. 
151. Duan, Y.; Tao, X.; Zhao, H.; Xiao, X.; Li, M.; Wang, J.; Zhou, M. Activity of demethylation inhibitor fungicide metconazole on Chinese Fusarium graminearum species complex and its application in carbendazim-resistance management of Fusarium head blight in wheat. Plant Dis. 2019, PDIS-09. [CrossRef]

152. Audenaert, K.; Callewaert, E.; Höfte, M.; De Saeger, S.; Haesaert, G. Hydrogen peroxide induced by the fungicide prothioconazole triggers deoxynivalenol (DON) production by Fusarium graminearum. BMC Microbiol. 2010, 10, 112. [CrossRef] [PubMed]

153. Li, J.; Duan, Y.; Bian, C.; Pan, X.; Yao, C.; Wang, J.; Zhou, M. Effects of validamycin in controlling Fusarium head blight caused by Fusarium graminearum: Inhibition of DON biosynthesis and induction of host resistance. Pestic. Biochem. Phys. 2019, 153, 152-160. [CrossRef]

154. Liu, Z.; Zhao, L.; He, X.; Wang, J. Screening fungicides for controlling Fusarium head blight of winter wheat. Agri. Sci. Tech. 2017, 18, 2495-2502.

155. Liang, B. The effects of different processing techniques of flour on deoxynivalenol (DON) content in wheat Flour. Anhui J. Prev. Med. 2004, 10, 138-139.

156. Li, F.; Gu, S.Q.; Lu, D.X.; Zhao, Y. The effect of combined separation on reduction of DON toxin in wheat. J. Chin. Cereal. Oil. Ass. 2014, 29, 12-15.

157. Bian, K.; Guan, E.Q.; Li, M.M.; Gui, G.J.; Zhang, K.; Guo, W.H.; liu, Y.X. Study of methods to eliminate and remove of vomitotoxin from scabby wheat. In Proceedings of the Academic symposium on the 30th anniversary of the establishment of the storage branch of the Chinese food and oil association, Chengdu, China, 2015; pp. 195-208.

158. Zhu, Y.C.; Zhou, L.; Xing, F.G.; Zhao, Y.J.; Wang, Y.; Liu, Y. An improved gravity separation technology for sorting deoxynivalenol-contaminated wheat. J. Chin. Inst. Food Sci. Tech. 2015, 15, 121-127.

159. Guan, E.Q.; Gui, G.J.; Bian, K.; Zheng, Z.H. SIMCA identification model establishment of gibberellic disease wheat grain based on near infrared spectrum characteristics. J. Chin. Cereal. Oil. Ass. 2016, 31, 124-129.

160. Liang, K.; Du, Y.Y.; Lu, W.; Wang, C.; Xu, J.H.; Shen, M.X. Identification of Fusarium head blight wheat based on hyperspectral imaging technology. Trans. Chin. Soc. Agric. Mach. 2016, 47, 309-315.

161. Du, Y.Y.; Chen, X.H.; Liang, K.; Xu, J.H.; Shen, M.X.; Lu, W. Identification of deoxynivalenol content in wheat based on the hyperspectral image system. Sci. Tec. Food Ind. 2016, 37, 54-58.

162. Shen, F.; Liu, X.; Pei, F.; Li, P.; Jiang, D.F.; Liu, Q. Rapid identification of deoxynivalenol contamination in wheat and its products by attenuated total reflectance-fourier transform infrared spectroscopy (ATR-FTIR). Food Sci. 2019, 40, 293-297.

163. Hou, R.; Yu, Y.G.; Ma, H.R.; Huang, R.; Wang, L.N.; Xiao, X.L. Effect of cleaning and milling on removal of deoxynivalenol in wheat and flour quality. Cereal Feed Sci. 2016, 5, 6-11. 